$\checkmark$ Research Square

\title{
In-vitro and In-silico approach for characterization of antimicrobial-peptide from probiotics against Staphylococcus aureus and Escherichia coli
}

\section{Amrutha Bindu}

University of Mysore

Lakshmidevi N ( $\square$ lakshmiavina@rediffmail.com )

University of Mysore https://orcid.org/0000-0003-0280-3029

\section{Research Article}

Keywords: bacteriocin, lactic acid bacteria (LAB), probiotic, plantaricin, lactobacillus, MIC

Posted Date: April 21st, 2021

DOI: https://doi.org/10.21203/rs.3.rs-366314/v1

License: (c) (i) This work is licensed under a Creative Commons Attribution 4.0 International License.

Read Full License 


\section{Abstract}

The present aim was to determine the characteristic feature and stability of antimicrobial compound (AMC) produced by probiotic strains of Enterococcus durans MCC4243, Lactiplantibacillus plantarum (Basanym: Lactobacillus plantarum MCC4246) and Limosilactobacillus fermentum (Basonym: Lactobacillus fermentum MCC4233) against Staphylococcus aureus MTCC96 and Escherichia coli MTCC118. Growth kinetic assay revealed 24h of incubation to be optimum for bacteriocin production. Ammonium sulphate precipitation-dialysis was found to be favorable method for extraction of AMC compared to other methods employed. The partially purified compound after ion-exchange chromatography was found to be thermo-resistant upto $90^{\circ} \mathrm{C}$ and stable under wide range of $\mathrm{pH}$. The compound was sensitive to proteinase- $\mathrm{K}$, but resistant to trypsin, $\mathrm{a}$-amylase and lipase. The apparent molecular weight of AMC from MCC4243 and MCC4246 was found to be 3.5KDa. PCR confirmed the presence of plantaricinA gene in MCC4246. Translated partial amino acid sequence of plnA gene of MCC4246 displayed 48 amino acid sequence which had $100 \%$ similarity with plantaricinA of Lactobacillus plantarum (WP 0036419). The sequence revealed $7 \beta$ sheets, 6 a sheets, 6 predicted coils and 9 predicted turns and functions on cytoplasm with 10.82 isoelectric point and $48.6 \%$ hydrophobicity. From the study, the amino acid sequence "KSSAYSLQMGATAIKQVKKLFKKWGW" of peptide was predicted to be responsible for antimicrobial activity.

\section{Introduction}

In recent years, people are being attracted towards consumption of food, positively associated with health and nutrition. The attitude towards un-acceptance of food products containing some of the artificial preservatives has increased due to growing awareness of its ill-effect on human and animal health (Anand and Sati 2013). Hence it is a major challenge in food sector to satisfy consumers demand for products free of chemical preservatives and also to ensure natural means of food safety. Further, the chemically synthesized antibiotics and their non judicious usage has resulted in emerging multidrug resistant pathogens and their devastating damage thereafter. Consequently, the need for new strategies and methodologies to control infectious pathogens is increasing. The health benefits executed by some of the traditional foods have attracted researchers to dig the mechanism and apply the knowledge for betterment of life. In this regard, antimicrobial compounds (AMC) or the bacteriocins from food grade lactic acid bacteria ( $L A B$ ) have engrossed because of its safety and broad range of antibacterial spectrum.

Bacteriocins are ribosomally synthesized proteinaceous compound produced by bacteria to protect themselves as well as to competitively colonize in the gut through elimination of undesirable organisms. Bacterial ability to inhibit spoilage organisms has been exploited for its application as natural preservatives in various food formulations. LAB being the natural microflora of human intestine has added advantage for its application in food due to their GRAS (Generally recognized as Safe) status. Bacteriocins from LAB are of low molecular peptides which vary in their size, post-translation modifications, stability and mode of action (Amortegui et al. 2014). According to Drider et al (2006) and 
Nes and Holo (2000) bacteriocins, have been classified into 3 groups based on presence or absence of post-translational modification: Class I-Lantibiotics containing lanthionine or ß-methyl-lanthionine; Class II- heat stable unmodified bacteriocins; Class III-large heat liable bacteriocin. Class II bacteriocins are further subdivided into Class Ila (one peptide), Class IIb (two peptide), Class IIc (circular), Class IId (unmodified, linear, non-pediocin like) and Class Ile (Microcin like). Class Ila bacteriocins are $<10 \mathrm{kDa}$ in size with 37-48 amino acids that inhibit growth of food spoilage organisms such as Listeria monocytogenes, Bacillus cereus, Clostridium perfringens, Staphylococcus aureus and E. coli (Rodrigues et al. 2005).

Bacteriocin produced by Lactococcus lactis subsp. lactis ie., Nisin is the only bacteriocin approved by USFDA for commercial application in food products. However the application of nisin is limited in neutral and alkaline $\mathrm{pH}$. Long-time preservation of foods by biopreservative process and inhibition of pathogenic microbes through natural means is therefore universal need in the present scenario. Considering this, the present work was carried out to optimize the method for efficient extraction of antimicrobial compound (AMC) from $L A B$ isolated from fermented foods. These $L A B$ cultures including Enterococcus durans DB1aa (MCC4231), Enterococcus faecium DB-b2-15b (MCC4263), Lactiplantibacillus plantarum (Basanym: Lactobacillus plantarum Cu2-PM7 (MCC4246), Limosilactobacillus fermentum (Basonym: Lactobacillus fermentum Cu3-PM8 (MCC4233) and Lactobacillus fermentum IB-PM15 have been previously characterized for their potential probiotic properties (Bindu and Lakshmidevi 2020). In the present study, we report the effect of physical and chemical parameter on the activity of partially purified AMC and PCR approach has been applied for characterization of antimicrobial peptide.

\section{Materials And Methods}

\section{Bacterial cultures and growth condition}

The selected probiotic cultures Enterococcus durans DB-1aa (MCC4231), Enterococcus faecium DB-b215b (MCC4263), Lactobacillus plantarum Cu2-PM7 (MCC4246), Lactobacillus fermentum Cu3-PM8 (MCC4233) and Lactobacillus fermentum IB-PM15 were isolated from fermented food products, identified and deposited at Microbial Culture Collection Center, Pune (Bindu and Lakshimidevi 2020). Recently, Lactobacillus plantarum has been classified as Lactiplantibacillus plantarum and Lactobacillus fermentum as Limosilactobacillus fermentum (Zheng et al. 2020). They were grown in deMann Rogosa Sharpe (MRS) medium at $37^{\circ} \mathrm{C}$ for $16-18 \mathrm{~h}$. To study the properties of AMC two indicator organisms ie., Staphylococcusaureus MTCC 96 and Escherichia coli MTCC 118 were used. The indicator bacteria were grown in Brain Heart Infusion (BHI) media at $37^{\circ} \mathrm{C}$ under constant shaking condition (120 rpm). The selected cultures were stored under $40 \%$ glycerol at $-20^{\circ} \mathrm{C}$ until use.

\section{Antimicrobial activity of selected probiotic cultures}

Antimicrobial activity was tested by the agar well diffusion assay as described by Xie et al. (2009). Each experiment was carried out in triplicates and the mean diameter of the inhibition zone was measured in $\mathrm{mm}$ and recorded. Antibiotic chloramphenicol $(1 \mathrm{mg} / \mathrm{ml})$ was used as positive control. The inhibitory 
activity was further quantified by the two-fold dilution method. Briefly, cell suspension of pathogenic culture grown in $\mathrm{BHI}$ broth was adjusted to turbidity of $0.5 \mathrm{McF}$ arland which is equivalent to $1-2 \times 10^{5}$ $\mathrm{CFU} / \mathrm{mL}$. Antibacterial activity was quantified by testing the two fold serially diluted sample of AMC by agar well diffusion assay and the results were expressed as AU/ml. Arbitrary unit (AU) is defined as the reciprocal value of the highest dilution at which the zone of inhibition is observed.

\section{Minimum Inhibitory Concentration (MIC)}

MIC was estimated by using different concentration of the sample (10-100 $\mu \mathrm{g})$ in a 96 well ELISA plate. Freshly, grown pathogenic cultures at a final concentration of $10^{5} \mathrm{CFU} / \mathrm{mL}$ was inoculated into each well and the plate was incubated at $37^{\circ} \mathrm{C}$ for $24 \mathrm{~h}$. Chloramphenicol $(5-50 \mu \mathrm{g})$ was used as a positive control and sample with un-inoculated broth as negative control. After incubation absorbance was measured at $600 \mathrm{~nm}$. MIC was defined as the lowest protein concentration (in $\mathrm{mg} / \mathrm{mL}$ ) which inhibited the growth of pathogenic culture completely. All assays were performed in triplicate.

\section{Determination of proteinacious nature of AMC}

The proteinacious nature of AMC was checked agar well diffusion assay by treating the crude AMC with proteinase $\mathrm{K}$ at a final concentration of $2 \mathrm{mg} / \mathrm{ml}$ for $30 \mathrm{~min}$. The untreated CFS and the enzyme alone in buffer ( $\mathrm{pH}$ 7.0) served as controls.

\section{Probiotic growth and AMC production}

Growth kinetics and AMC production was studied for a period of 5 days. The selected cultures were inoculated $(1 \% \mathrm{v} / \mathrm{v})$ in $250 \mathrm{ml}$ MRS broth and incubated at $37^{\circ} \mathrm{C}$ without agitation. An aliquot of sample was drawn after every $12 \mathrm{~h}$ during growth and checked for bacterial growth and antimicrobial activity. Bacterial growth was determined by measuring cell density at $600 \mathrm{~nm}$. The antimicrobial activity was evaluated after filter sterilizing the neutralized CFS by well diffusion assay.

\section{Extraction of the AMC}

\section{Optimization of the extraction procedure}

The CFS of the selected probiotic cultures was subjected to various extraction procedures to determine a suitable protocol for maximum recovery of AMC. Protocol 1: CFS was mixed with ice-cold ethanol (1:1 $\mathrm{v} / \mathrm{v}$ ) and allowed for precipitation overnight at $4^{\circ} \mathrm{C}$. The precipitate was air-dried, resuspended in phosphate buffer ( $\mathrm{pH} 7.0)$ and checked for inhibitory activity. Protocol 2: CFS was blended with equal volumes of chloroform on a magnetic stirrer for $1 \mathrm{~h}$. The mixture was left at room temperature undisturbed for phase separation. AMC in the interphase was collected carefully and the residual chloroform was evaporated under nitrogen and monitored for the inhibitory activity. Protocol 3: Fine powder of ammonium sulfate was added slowly to the CFS until a saturation level of $80 \%$ under constant stirring. The procedure was followed at $4^{\circ} \mathrm{C}$ under aseptic condition. The precipitate obtained was dialyzed against phosphate buffer $(\mathrm{pH} 7.0)$ with three changes of buffer and then analyzed for inhibitory 
activity. Protocol 4: Butanol (1: $0.5 \mathrm{v} / \mathrm{v})$ was added to CFS and vigorously mixed in a separating funnel. The mixture was left at room temperature for phase separation. The butanol layer was carefully collected and evaporated to dryness using rotary evaporator and checked for the activity.

\section{lon exchange chromatography}

The dialyzed sample (60 mg protein) of each culture was loaded separately onto a DEAE cellulose column $(18 \times 3 \mathrm{~cm})$ pre-equilibrated with sodium phosphate buffer $(0.2 \mathrm{mM} ; \mathrm{pH} 7.0)$. A linear gradient of $0.0-1.0 \mathrm{M} \mathrm{NaCl}$ in the same buffer was used to elute the protein fractions at a flow rate of $1 \mathrm{ml} / \mathrm{min}$. Fractions $(2 \mathrm{ml})$ was collected and checked for absorbance at $280 \mathrm{~nm}$. The fractions showing the highest protein content were pooled, lyophilized and examined for antimicrobial activity.

\section{Stability of partially purified AMC}

\section{Effect of Temperature and $\mathrm{pH}$}

The effect of temperature was evaluated by incubating the partially purified AMC for 30 min at different temperatures $\left(30,40,50,60,70,80,90^{\circ} \mathrm{C}\right)$. The residual activity was checked by agar well diffusion assay after cooling to room temperature. The effect of $\mathrm{pH}$ was studied by adjusting the AMC to different $\mathrm{pH}$ (39) using $1 \mathrm{M} \mathrm{NaOH}$ or $1 \mathrm{M} \mathrm{HCl}$. The sample was incubated at $37^{\circ} \mathrm{C}$ for $30 \mathrm{~min}$. The inhibitory activity was later checked after neutralization of AMC.

\section{Effect of enzymes}

The effect of enzymes such as trypsin, amylase and lipase on inhibitory activity was evaluated by treating the partially purified AMC with each enzyme at a final concentration of $1 \mathrm{mg} / \mathrm{ml}$. Samples were incubated at $37^{\circ} \mathrm{C}$ for $30 \mathrm{~min}$. After incubation, samples were heat treated at $90^{\circ} \mathrm{C}$ for $5 \mathrm{~min}$ to inactivate the enzymes and then the residual activity was determined as described earlier.

\section{Sodium dodecyl sulfate-polyacrylamide gel electrophoresis (SDS-PAGE) and overlay assay to detect AMC}

Crude sample, dialyzed sample as well as column purified fractions of bacteriocin were subjected to SDSPAGE (Laemmli 1970) along with low range protein marker ranging from 3.5-43 KDa. The antimicrobial activity in the partially purified sample was determined by overlay assay (Barboza-Corona et al. 2007). The sample containing $80 \mu \mathrm{g}$ of protein was mixed with equal volume of non-reducing loading buffer and directly loaded in the SDS-PAGE gel without boiling. Following electrophoresis, the gel was cut vertically and immersed in fixing solution (25\% isopropanol, $10 \%$ acetic acid) for $1 \mathrm{~h}$ and washed with doubledistilled water with three changes after every $30 \mathrm{~min}$. Later, the gel was sterilized by exposing to UV for 30 min and then aseptically placed in a sterile petriplate and overlaid with $\mathrm{BHI}$ agar pre-inoculated with $1 \%$ (equivalent to $10^{8} \mathrm{CFU} / \mathrm{ml}$ ) overnight grown test organism (Staphylococcus aureus or E. coli). The petriplate was later incubated at $37^{\circ} \mathrm{C}$ for $24 \mathrm{~h}$ and observed for the presence of inhibition zone.

Detecting bacteriocin genes by polymerase chain reaction (PCR) 
The presence of bacteriocin gene was identified in L. plantarum Cu2-PM7 using plantaricin A (F: GTA CAG TAC TAA TGG GAG; R: CTT ACG CCA ATC TAT ACG) and P1/P2 primers (F: AAAATATCTAACTAATACTTG; R: TAAAAAGATATTTGACCAAAA). The gene was amplified in $25 \mu \mathrm{l}$ reaction mixture containing $2 \mu \mathrm{l}$ of $1 \mathrm{X}$ PCR buffer, $1.5 \mu \mathrm{l}$ of $\mathrm{MgCl}_{2}, 5 \mu \mathrm{l}$ of dNTPs, $0.5 \mu \mathrm{l}$ of each (Forward and reverse) primer, $2.5 \mathrm{U}$ of Taq polymerase and $100 \mathrm{ng}$ of genomic DNA. PCR conditions include denaturation at $95^{\circ} \mathrm{C}$ for $5 \mathrm{~min}$ followed by $35 \mathrm{cycles}$ of denaturation at $95^{\circ} \mathrm{C}$ for $30 \mathrm{sec}$, annealing at $50^{\circ} \mathrm{C}$ for pln primer and $52^{\circ} \mathrm{C}$ for P1/P2 primer, for $45 \mathrm{sec}$ and extension at $72^{\circ} \mathrm{C}$ for $1 \mathrm{~min}$ and final extension of $72^{\circ} \mathrm{C}$ for $10 \mathrm{~min}$. The amplified PCR product was sequenced at GENESPY Research Services, Mysore. Sequence was matched with similar sequence from NCBI data base.

\section{Bacteriocin peptide analysis}

Bacteriocin peptide structure for the putative amino acid was predicted by using Geneious Prime $\circledast$ 2019.2.1 Software (Kearse et al. 2012). Using the software, secondary structure, antigenic regions, signal cleavage sites, transmembrane regions and protein domains prediction plugins was determined. Further the amino acid sequence data was analyzed. The peptide showing activity was later analyzed by using protein predict server (https://open.predictprotein.org/) followed by PDB database (Armstrong et al. 2020).

\section{Statistical analysis}

The experiments were conducted in triplicates and the data analysis was done using STATISTICA version 6 software (Statsoft Inc., Tulsa, USA). The significant different between the samples were analyzed by using ANOVA (analysis of variance), and the mean separation was accomplished by Duncan's multiple range test.

\section{Results}

\section{Minimum inhibitory concentration of AMC}

According to the results obtained, MIC was in the range of 2200 to $2400 \mu \mathrm{g}$ against $S$. aureus and E. coli. Higher activity against $S$. aureus $(228.6 \mathrm{AU} / \mathrm{mg})$ and $E$. coli $(114.3 \mathrm{AU} / \mathrm{mg})$ was noticed in AMC of $L$. plantarum Cu2-PM7, followed by L. fermentum Cu3-PM8 (139.1 and 69.6 AU/mg against $S$. aureus and $E$. coli respectively). Enterococcus faecium DB-b2-15b displayed lowest activity (38.1 and $38.1 \mathrm{AU} / \mathrm{mg}$ against $S$. aureus and E. coli respectively). Based on the data, three cultures viz., Enterococcus durans DB1aa, L. plantarum Cu2-PM7 and L. fermentum CU3-PM8, showing higher activities were selected for further study.

\section{Proteinaceous nature of AMC from probiotic culture}

Proteinaceous nature of the neutralized CFS was confirmed by treating with proteinase $\mathrm{K}$. According to the results obtained, the activity was not lost after neutralization but was significantly reduced on treating 
with proteinase $\mathrm{K}$. This confirms that the inhibitory activity was not due to acidity but was due to proteinaceous compound.

\section{Growth kinetics and bacteriocin production}

The selected cultures entered the late exponential phase in $24 \mathrm{~h}$ and remained constant in stationary phase upto 5 days. The OD (optical density) at $600 \mathrm{~nm}$ is presented in Table 1. Inhibition zone in the range of 12-16 mm dia was observed upto 3 days against $S$. aureus. On day $4^{\text {th }}$ and $5^{\text {th }}$, no activity was observed. MIC against $S$. aureus was $2400 \mu \mathrm{g}$ for all the tested AMC after $24 \mathrm{~h}$ of growth (Table 1 ). However on the $5^{\text {th }}$ day MIC was 5200, 5000 and $3800 \mu \mathrm{g}$ for AMC from DB-1aa, Cu2-PM7 and Cu3-PM8 respectively. Activity was highest at $24^{\text {th }} \mathrm{h}$, later the activity gradually decreased. According to the data obtained, maximum activity (266.02 AU/mg) was noticed in L. plantarum Cu2-PM7. The AMC compound of Cu2-PM7 and Cu3-PM8 showed inhibitory activity against $E$. coli upto 5 days, but DB-1aa displayed zone of inhibition upto 3 days (Table 1). With increase in incubation days, a gradual reduction in the size of inhibition zone was observed. The MIC was $2400 \mu \mathrm{g}$ on the $1^{\text {st }}$ day but displayed 5600,5200 and 3800 $\mu \mathrm{g}$ on the $5^{\text {th }}$ day. The activity was maximum (133.01 AU/mg) with L. plantarum Cu2-PM7 after $24 \mathrm{~h}$ of incubation.

\section{Extraction of AMC from selected cultures}

AMC from selected cultures was extraction by four different techniques to determine the best method for extraction of AMC. Ethanol precipitation did not show any inhibitory activity against $S$. aureus, however against $E$. coli lesser zone of inhibition (10 mm dia) was observed (Fig. S1). Comparatively, sample after ammonium sulphate precipitation-dialysis displayed maximum zone of inhibition than chloroform extract and butanol extract (Table 2). MIC against S. aureus was in the range of $1900-2200 \mu \mathrm{g}$ and $2000-$ $2300 \mu \mathrm{g}$ against $E$. coli. According to the data obtained, ammonium sulphate precipitation-dialysis was found to be the best method for extraction which showed an activity of 155.27, 212.72 and 179.80 $\mathrm{AU} / \mathrm{mg}$ with $E$. durans DB-1aa, L. plantarum Cu2-PM7 and L. fermentum Cu3-PM8 respectively. Hence, further step of purification was carried out after ammonium sulphate precipitation and dialysis.

\section{Purification of bacteriocin by ion exchange chromatography}

Fig. S2 display the inhibitory activity of crude CFS and ammonium sulphate precipitated- dialyzed sample of each isolate. An increase in the inhibition zone size could be observed in the dialyzed sample. Further, ion-exchange chromatography was carried out using DEAE cellulose column as a next step of bacteriocin purification. As shown in Fig. 1, the sample from each culture was separated into three fractions. Protein fraction of DB-1 aa was eluted between $0.06-0.2 \mathrm{M}$ (fraction 1), $0.24-0.4 \mathrm{M}$ (fraction 2) and $0.4-1.0$ $\mathrm{M}$ (fraction 3). In case of Cu2-PM7 elute from 0.06-0.36 M, 0.45- $0.6 \mathrm{M}$ and $0.63-1.0 \mathrm{M}$ was considered as fraction 1, 2 and 3 respectively. Similarly, in Cu3-PM8 fractions from $0.06-0.33 \mathrm{M}, 0.48-$ $0.6 \mathrm{M}$ and $0.63-1.0 \mathrm{M}$ was selected. The elutent of each peak was collected and concentrated by lyophilization. The antimicrobial activity assay confirmed the zone of inhibition in fraction 1 and 2 of all 
the three culture against $S$. aureus and $E$. coli (Fig. 1). The data obtained revealed highest inhibition zone of 20 and $18 \mathrm{~mm}$ against $S$. aureus and E. coli by fraction-1 of L. plantarum Cu2-PM7 with MIC of 1200 and $1300 \mu \mathrm{g}$ respectively. The details of purification data are summarized in Table 3 . The final yield of bacteriocin obtained after ion-exchange chromatography was $0.4,0.5$ and $0.4 \%$ for DB-1aa, Cu2-PM7 and Cu3-PM8 respectively against $S$. aureus. Correspondingly, a final yield of $0.35,0.76$ and $0.68 \%$ was found against E. coli.

\section{Effect of temperature and $\mathrm{pH}$ on bacteriocin activity}

According to the results obtained, the bacteriocins from all the tested cultures were active in all the temperature tested (Table 4). However, bacteriocin from Cu3-PM8 showed slight reduction in the activity at higher temperature. Further, the $\mathrm{pH}$ stability of bacteriocin purified from selected probiotic culture was analyzed at various $\mathrm{pH}$ ranging from $\mathrm{pH}$ 3-10 (Table 5). The data revealed that the inhibitory activity was more active at acidic $\mathrm{pH}$ (inhibition zone ranging from $14-20 \mathrm{~mm}$ dia). As the $\mathrm{pH}$ approached neutral, the activity reduced and was completely inhibited at alkaline $\mathrm{pH}$.

\section{Effect of enzymes on bacteriocin activity}

According to the data obtained, the inhibitory activity was retained in all the three bacteriocin after treating with a-amylase and lipase. However, in presence of trypsin 55, 34 and 43\% activity was retained.

\section{SDS-PAGE analysis of antimicrobial compound}

Molecular weight of the antimicrobial compound from selected probiotic culture (Cu2-PM7 and Cu3-PM8) was determined by SDS-PAGE (Fig. 2). Accordingly, apparent molecular weight of both AMC was found to be $3.5 \mathrm{kDa}$. Inhibition zone corresponding to their respective protein bands was developed on performing activity assay by overlaying indicator strain (Fig. 2).

\section{Detecting plantaricin gene by PCR}

PCR analysis of plantaricin gene was carried out in Cu2-PM7 using plnA and P1/P4 primer. A good amplification of $450 \mathrm{bp}$ was observed with plnA F/R primer. On the other hand, no amplification was detected with P1/P4 primer. The control culture, E. durans DB-1 aa did not show any amplification in presence of any of the tested primer. Further, the PCR product was sequenced and the obtained sequence was subjected to BLASTn search in NCBI database and aligned with hit sequences. The results indicated $100 \%$ homology with plantaricin plnA sequence of Lactobacillus plantarum strain EG.LP 18.7 (MN172266.1) (Fig. 3).

The nucleotide sequence was translated to aminoacid sequence and checked for homology with BLAST search. Translated partial amino acid sequence of $p / n$ A gene of Cu2-PM7 displayed 48 amino acid 
sequence which had $100 \%$ similarity with plantaricin A of L. plantarum (WP 0036419). Fig. 4 represents the similarity of plnA-PM7 amino acid sequence with related sequence from NCBI data base.

\section{Bacteriocin peptide analysis}

The pln A gene sequence was translated and the 138 amino acid sequence thus obtained was studied for its structural and functional properties. It was observed that the partial sequence of Cu2-PM7 possessed 10.82 isoelectric point and $48.6 \%$ hydrophobicity. The sequence possessed $7 \beta$ sheets, 6 a sheets, 6 predicted coils and 9 predicted turns and functions on cytoplasm. One topological domain, which encodes the bacteriocin-like signal sequence (MKQLSNKEMQKIVGG) was noticed with a GG cleavage motif at their $\mathrm{N}$-terminal region. Further, four antigenic regions were detected in the acquired sequence which were located at sites 6-26, 28-46, 65-77 and 122-135 with sequence read

\section{LSILRCAVNVILSSKYVQSNQ, LFKIVTLTFIKYLIALEFH, THYPKSEVIIMKI and WLIYITVFQVIFRIDGV,}

respectively. A 3D structure for the bacteriocin-like peptide was inferred from Phyre2 and indicated alpha and beta sheet structure fragments (Fig. 5). The protein-predict database showed maximum homology towards bacteriocin plantaricin A of Lactobacillus plantarum WCFS1, with the ID P80214. Hence, it can be perceived that the amino acid sequence stretch of our native isolate Cu2-PM7 possessed

“KSSAYSLQMGATAIKQVKKLFKKWGW" peptide showing a molecular weight of $3 \mathrm{kDa}$.

\section{Discussion}

The increasing awareness among consumers about the side effect caused by some of the chemically synthesized artificial preservatives motivated the study to characterize bacteriocins from probiotic culture that can positively enhance the characteristic taste, wellness and safety of the product. The present probiotic cultures were isolated from fermented food and were shown to exhibit potential probiotic properties (Bindu and Lakshmidevi 2020). The selected cultures showed acid and bile tolerance, gastrointestinal survival, good adhesion property and also possible functional properties including antioxidant activity and industrially important enzyme production. The selected probiotic cultures displayed large spectrum of inhibitory activity against pathogenic and spoilage bacteria including Micrococcus luteus, Staphylococcus aureus, Listeria monocytogenes, Bacillus subtilis, Klebsiella sp., E. coli, Pseudomonas aeroginosa, Yersinia enterocolitica, Salmonella sp, and Enterobacter aeroginosa. In the view of their probiotic candidacy, the AMC from these cultures were characterized in the present investigation.

Each indigenous strain exhibited a variable titre and pattern of inhibition against selected pathogens. On the context of inhibitory activity of all the selected probiotic culture, studies were continued with Staphylococcus aureus and E. coli as indicator organisms because of their know pathogenecity (Croxen et al. 2013; Kadariya et al. 2014). According to the results obtained, inhibitory activity against $S$. aureus and E. coli was in the following increasing order: DB-b2-15b < DB-1 aa < IB-PM15 < Cu3-PM8 < Cu2-PM7. Further studies were therefore continued with DB-1aa, Cu2-PM7 and Cu3-PM8. 
Generally, bacteriocins are proteinaceous compound produced by certain bacteria to hinder the growth of similar or closely related strains. Hence, to confirm the proteinaceous nature of the AMC, the cell free supernatant (CFS) of the probiotic culture was treated with proteinase K. The enzyme "proteinase K" is a serine protease responsible for degradation of protein. Accordingly, the CFS treated with the enzyme was unable to inhibit the pathogen indicating the denaturation of proteinaceous compound present in CFS which is responsible for antimicrobial activity. As these probiotic cultures are lactic acid bacteria, the action of lactic acid was initially nullified by adjusting the pH of CFS to7.0 using $1 \mathrm{~N} \mathrm{NaOH}$.

Growth kinetic studies reveal that the selected probiotic cultures enter late exponential phase within $24 \mathrm{~h}$ and in stationary phase for the next 5 consecutive days tested. With respect to $S$. aureus, inhibitory activity was noticed upto 3 days, later reduction or no activity was seen. In case of $E$. coli, inhibitory activity was observed upto 5 day. Maximum activity was determined in Cu2-PM7 after $24 \mathrm{~h}$ against $S$. aureus (266.02 AU/mg) and E. coli (133.01 AU/mg). Bello et al. (2018) have shown bacteriocins from $L$. plantarum $\mathrm{Z} 1116$ with $500 \mathrm{AU} / \mathrm{ml}$ at the $9^{\text {th }}$ hour. The inhibitory activity gradually increased and reached $12,000 \mathrm{AU} / \mathrm{ml}$ after $18^{\text {th }}$ hour of growth in MRS broth at $30^{\circ} \mathrm{C}$ where high cell density $\left(6.8 \mathrm{OD}_{600} \mathrm{~nm}\right)$ was recorded. In the same study, Enterococcus faecium AU02 and Leuconostoc lactis PKT0003 showed highest level of bacteriocins activity $(3200 \mathrm{AU} / \mathrm{ml}$ and $1600 \mathrm{AU} / \mathrm{ml})$ at $21^{\text {st }}$ and $24^{\text {th }} \mathrm{h}$ of growth where highest (2.8 and $2.75 \mathrm{OD}_{600} \mathrm{~nm}$ ) cell density was recorded. Milioni et al. (2015) compared bacteriocin production of Lactobacillus plantarum LpU4 grown in MRS broth and MRS broth buffered with citrate at $25^{\circ} \mathrm{C}$. In normal MRS broth, the antimicrobial activity was initiated at the beginning of the exponential phase reaching a maximum $(1,600 \mathrm{AU} / \mathrm{ml})$ at late exponential phase $(24 \mathrm{~h})$ and remained constant during the stationary phase upto $48 \mathrm{~h}$. In buffered MRS broth, the activity increased from 100 to 3,200 $\mathrm{AU} / \mathrm{ml}$ during the exponential growth phase and was stable until $48 \mathrm{~h}$. According to Barbosa et al. (2013), the optimum condition for bacteriocins production $(1600 \mathrm{AU} / \mathrm{ml})$ was $25^{\circ} \mathrm{C}$ and $20 \mathrm{~h}$ of incubation time.

As a first step of purification, the AMC was subjected to various extraction techniques for optimum yield. Accordingly, ammonium sulphate precipitation-dialysis technique was found to be more favorable compared to chloroform extraction, ethanol precipitation or butanol extraction. Likewise, Song et al. (2014) used ammonium sulphate precipitation as first step of bacteriocin purification from Lactobacillus plantarum ZJ5 and reporter an activity of $317.14 \mathrm{AU} / \mathrm{mg}$. Earlier studies have reported most of the bacteriocin to contain positively charged amino acid residues with hydrophobic features (Barbosa et al. 2013). Hence, ion exchange chromatography is the commonly applied strategy which has been successfully used for purification of bacteriocin. In the present investigation, therefore ion exchange chromatography has been applied for purification of AMC. According to the data obtained, increase in the purification fold of 2.75, 1.87 and 1.92 was noticed with respect to DB-1aa, Cu2-PM7 and Cu3-PM8 against $S$. aureus. With regard to $E$. coli, purification fold of $2.4,2.84$ and 3.26 was perceived. Song et al. (2014) obtained $1.7 \%$ yield after RP-HPLC purification of plantaricin from Lactobacillus plantarum ZJ5. In another study, RP-HPLC purified bacteriocin from Lactobacillus sakei showed $74949.6 \mathrm{AU} / \mathrm{mg}$ activity with $32 \%$ yield and 40.05 fold increase in the activity as tested against Enterococcus faecalis J2-2 (Barbosa et al. 2013). 
Stability study of partially purified AMC at different temperature revealed that the compound is resistant upto $90^{\circ} \mathrm{C}$. Earlier literature also support the data that the AMC from Lactobacillus plantarum are heat stable (Todorov 2009). Earlier studies have shown bacteriocins stable upto $60^{\circ} \mathrm{C}$ (Nowroozi et al. 2004; Sowani and Thorat 2012; Martinez et al. 2013), however at higher temperature above $80^{\circ} \mathrm{C}$, a significant reduction in the antimicrobial activity has been reported. In the present study, the tested bacteriocin was stable even at $90^{\circ} \mathrm{C}$. Similar results of temperature stability have also been reported for bacteriocins LPBM10, bacST202Ch, bacST216Ch, enterocin AS-48, and plantaricin OL15 (Mourad et al. 2005; Zapata et al. 2009; Todorov et al. 2010). Barbosa et al. (2013) have reported a anti-listerial bacteriocin from Lactobacillus sakei MBSa1 which is stable even at $121^{\circ} \mathrm{C}$ for $15 \mathrm{~min}$. Lactocin NK24 from Lactococcus lactis display $87 \%$ reduction in the inhibitory activity at $100^{\circ} \mathrm{C}$ and gets completely inactivated after steam sterilization (Lee and Paik 2001). Ferchichi et al. (2001) reports almost 25 and 8.3\% reduction in the antimicrobial activity of lactocin MMFIl, from Lactococcus lactis at 80 and $110^{\circ} \mathrm{C}$ respectively. Bacteriocin tolerance to higher temperature would be an essential property for their application in thermally processed food. In this regards, the three bacteriocins purified from the selected probiotic culture indicate their possible application as biopreservative agents.

The data on $\mathrm{pH}$ stability showed that the bacteriocins from the selected probiotic cultures are active at acidic $\mathrm{pH}$. The activity, however significantly reduced at neutral $\mathrm{pH}$ and alkaline $\mathrm{pH}$ Similarly, previous studies have reported that bacteriocins are highly stable at acidic $\mathrm{pH}$ but get inactivated at alkaline pH(Todorov et al. 2010; Hernandez et al. 2005). The bacteriocin with anti-listerial activity from Lactobacillus sakei MBSa1 was found stable at $\mathrm{pH} 2$ to 6 , but lost part of the activity at $\mathrm{pH} 8$ and 10 (Barbosa et al. 2013). Todorov and Dicks (2005) reports almost 50\% reduction in antimicrobial activity of bacteriocins ST28MS and ST26MS from L. plantarum at pH values lower than 4.0. Zapata et al. (2009) observed a marked reduction in the inhibitory activity of bacteriocin from L. plantarum LPBM10 with increase in $\mathrm{pH}$ value higher than 5. However, several studies have shown bacteriocins (ST23LD, ST341LD, bacST202Ch, bacST216Ch, and ST71KS) from Lactobacillus plantarum, which are stable between pH 2.0 and 12.0 (Todorov and Dicks 2005; Todorov et al. 2010; Martinez et al. 2013).

The effect of digestive enzyme such as trypsin, lipase and a-amylase on the bacteriocin activity was analyzed and the residual activity was determined. According to the data obtained, bacteriocin of the all the three selected cultures were stable in presence of lipase and a-amylase indicating the lack of carbohydrate or lipid moiety. However in presence of trypsin partial inactivation was observed.

SDS-PAGE analysis and over-lay assay revealed a molecular weight of bacteriocin to be $3.5 \mathrm{kDa}$ in both Cu2-PM7 and Cu3-PM8. Earlier reports confirms that the bacteriocin produced by Lactobacillus spp have molecular weight lower than $10 \mathrm{kDa}$ (Cintas et al. 2001; Cotter et al. 2013) as well as morethan $14 \mathrm{kDa}$ (Todorov et al. 2004; Todorov and Dicks 2006). In the similar line, bacteriocin-producing lactic acid bacteria (LAB) were isolated from fermented Parkia biglobosa seeds and were identified as Lactobacillus plantarum Z1116, Enterococcus faecium AU02 and Leuconostoc lactis PKT0003. They produced bacteriocins of size $3.2 \mathrm{kDa}, 10 \mathrm{kDa}$ and $10 \mathrm{kDa}$, respectively (Bello et al. 2018). Tome et al. (2009) partially purified bacteriocins from nine LAB isolated from vacuum-packaged cold-smoked salmon (CSS) 
which was active against Listeria monocytogenes, E. faecalis, E. faecium, and Staphylococcus aureus. The molecular size of bacteriocins ranged from 2.8 to $4.5 \mathrm{kDa}$. Messi et al. (2001) isolated LAB from italian sausages that produced plantaricin with a molecular weight of $4.5 \mathrm{kDa}$ which showed broad spectrum activity against food pathogens including S. aureus, L. monocytogenes and A. hydrophila. Lactobacillus plantarum SA6 isolated from fermented sausage produced a plantaricin peptide with molecular mass of $3.4 \mathrm{kDa}$. Amortegui et al. (2014) isolated Lactobacillus plantarum from ensiled corn and purified the bacteriocin by ammonium sulphate precipitation (70\%) and dialysis. They reported 5 and $10 \mathrm{kDa}$ protein with antagonistic activity against Listeria innocua, Listeria monocytogenes, and Enterococcus faecalis. Milioni et al. [16] characterized 4.8 kDa plantaricin from Lactobacillus plantarum which was isolated from sheep-milk cheese. Plantaricin IIA-1A5 active against Staphylococcus aureus was purified which showed single band on SDS-PAGE with apparent molecular weight of $6.4 \mathrm{kDa}$ (Arief et al. 2015).

In an attempt to determine the plantaricin gene in the selected probiotic strain L. plantarum Cu2-PM7, PCR was carried out using specific primers. As expected, an amplified product of $450 \mathrm{bp}$ was found with plnA F/R primer in L. plantarum Cu2-PM7. However no amplification was observed with P1/P4 primer. $E$. durans DB-1aa genomic DNA was used as control where no amplification was observed. The results indicate that the present strain $\angle$ plantarum Cu2-PM7 harbors the plantaricin A gene. BLASTn analysis of the sequence showed highest similarity with Lactobacillus plantarum strain EG.LP 18.7 (MN172266.1). Similarly, Remiger et al. (1996) reported the binding position of primer plnA5p and S7, outside the structural gene of plantaricin A, which allowed the amplification of 450 bp DNA fragment in L. plantarum strains. Earlier studies on comparative genome analysis have reported significant variation in the plantaricin operon in the gene cluster of Lactobacillus plantarum strains (Maldonado et al. 2004; RojoBezares et al. 2008). Ben Omar et al. (2008) isolated Lactobacillus strains from poto-poto, a congolese fermented maize product and observed significant variation in the number of genes between the strains. The operon of Pln locus of plantaricin encoding genes is either simple or complex (Diep et al. 2009). Devi and Halami (2019) reported different plantaricin types based on the presence or absence of pln genes.

The translated protein sequence of plnA gene of L. plantarum Cu2-PM7 showed 100\% homology with plantaricin A of L. plantarum (WP 0036419). As described by Diep et al. (1996), planatricin system in $L$. plantarum is organized into five operon. (1) plnABCD: The regulatory operon encoding bacteriocin -like peptide $(p \ln A)$, a histidine protein kinase ( $\mathrm{pln} B$ ) and two cytoplasmic response regulators ( $p \ln C$ and pln D). (2) pln GHSTUV: operon associated with transport (3) plnJKLR (4) pInMNOP (5) plnEF1 : related to plantaricin production and immunity. Plantaricin $A$ is a single peptide bacteriocin without post translational modification (Diep et al. 2009). They are included in subclass Ilc. L. plantarum CTC305 originally isolated from fermented sausage and L. plantarum $\mathrm{Cll}$ isolated from cucumber fermentation were shown to share the plantaricin A encoding gene plnA (Diep et al. 1994).

In the current analysis, bioinformatic tools were used to characterize the peptide nature. Geneious Prime software predicted the protein domain MKQLSNKEMQKIVGG which codes for bacteriocin like protein. On further analysis of this motif, it was observed that this motif is responsible for the entry of the bacteriocin 
peptide, with a GG cleavage motif at their $\mathrm{N}$-terminal region. The sequence also confirmed the presence of four antigenic regions at sites 6-26, 28-46, 65-77 and 122-135.

It is well known that bacteriocin encoding genes are found along with immunity proteins and other accessory proteins which are arranged in an operon cluster (Noda et al. 2018). In continuation, the bacteriocin-like signal sequence was targeted to predict the peptide which shows activity. The bacteriocin sequence showed maximum homology towards plantaricin A of Lactobacillus plantarum WCFS1, with the ID P80214. Further, the peptide with bacteriocin plantaricin-A had a PBD ID of IYTR, this ID possessed a sequence of 26 amino acids with 2.99 molecular weight (Fig. 5) (Kristiansen et al. 2005). Hence, it can be perceived that the amino acid sequence stretch of our native isolate Cu2-PM7 possessed

"KSSAYSLQMGATAIKQVKKLFKKWGW" peptide which is responsible for antimicrobial activity.

\section{Conclusions}

The data support the potential inhibitory activity of bacteriocin against Staphylococcus aureus and E. coli. On the basis of two important observations, i.e. proteinaceous nature of antagonistic substances and their heat stability, they can be considered as bacteriocins. The peptide analysis support the plantaricin A type bacteriocin present in the native probiotic culture L. plantarum Cu2-PM7. Overall the study highlights the characteristic features of bacteriocins produced from probiotic bacteria isolated from fermented foods which could be employed in food as preservative agent. The data obtained enhances our knowledge on the biocontrol of undesirable bacteria that could be used as an alternative therapy for treating infectious disease.

\section{Declarations}

Acknowledgements: This work was support by University Grants Commission for the award of NFSC research fellowship.

\section{Declarations}

Ethical Approval: This article does not contain any studies with human or animals

Consent for publication: This manuscript does not contain any individual person 's data.

Availability of data and material: Data sharing not applicable to this article as no datasets were generated or analyzed during the current study

Conflict of Interest: Dr. Lakshmidevi and Mrs. Amrutha Bindu declare that they have no conflict of interest

Funding: This work was support by University Grants Commission for the award of NFSC research fellowship. 
Authors contribution: Lakshmidevi and Amrutha Bindu conceived and designed the experiment. Amrutha Bindu conducted experiment and wrote the manuscript. Both the authors read and approved the manuscript for submission.

Authors' information: Dr. Lakshmidevi N is professor from Department of Microbiology, University of Mysore. She is expertise in bacterial metabolites, immunology and peptide analysis. Mrs. Amrutha Bindu is a research scholar doing her $\mathrm{PhD}$ in the same department.

Informed consent: Informed consent was obtained from both the participants included in the study.

\section{References}

1. Anand SP, Sati N (2013) Artificial preservatives and their harmful effects: Looking towards nature for safer alternatives. IJPSR 4(7):2496-2501.

2. Drider D, Fimland G, Héchard Y, McMullen LM, Prevost $H$ (2006) The continuing story of class lla bacteriocins. Microbiol Mol Biol Rev 70:564-582.

3. Nes IF, Holo H (2000) Class II antimicrobial peptides from lactic acid bacteria. Biopolymers (Peptide Science) 55:50-61.

4. Amortegui J, Rodriguez-Lopez A, Rodriguez D, Carrascal AK, Almeciga-Diaz CJ, Melendez ADP, Sanchez OF (2014) Characterization of a new bacteriocin from Lactobacillus plantarum LE5 and LE27 isolated from Ensiled corn. Appl Biochem Biotechnol 172(7): 3374-3389.

5. Rodrigues E, Calzada J, Arques JK, Rodriguez JM, Nunez M, Medina M (2005) Antimicrobial activity of pediocin-producing Lactococcus lactis on Listeria monocytogenes, Staphylococcus aureus and Escherichia coli 0157:H7 in cheese. Int Dairy J 5:51-57.

6. Bindu A, Lakshmidevi N (2020) Identification and in-vitro evaluation of probiotic attributes of lactic acid bacteria isolated from fermented food sources. Arch Microbiol DOI:10.1007/s00203-020-020370 .

7. Zheng J, Wittouck S, Salvetti E, Franz CMAP, Harris HMB, Mattarelli P, O'Toole PW, Pot B, Vandamme P, Walter J, Watanabe K, Wuyts S, Felis GE, Gänzle MG, Lebeer S (2020) A taxonomic note on the genus Lactobacillus: Description of 23 novel genera, emended description of the genus Lactobacillus Beijerinck 1901, and union of Lactobacillaceae and Leuconostocaceae. Int J Syst Evol Microbiol 70:2782-2858.

8. Xie J, Zhang R, Shang C, Guo Y (2009) Isolation and characterization of a bacteriocin produced by an isolated Bacillus subtilis LFB112 that exhibits antimicrobial activity against domestic animal pathogens. Afr J Biotechnol 8(20):5611-5619.

9. Laemmli UK (1970) Cleavage of structural proteins during the assembly of the head of bacteriophage T4. Nature 227:680-685.

10. Barboza-Corona JE, Vazquez-Acosta H, Bideshi DK, Salcedo-Hernandez R (2007) Bacteriocin-like inhibitor substances produced by Mexican strains of Bacillus thuringiensis. Arch Microbiol 187:117- 
1126.

11. Kearse M, Moir R, Wilson A, Stones-Havas S, Cheung M, Sturrock S, Buxton S, Cooper A, Markowitz S, Duran C, Thierer T, Ashton B, Meintjes P, Drummond A (2012) Geneious Basic: an integrated and extendable desktop software platform for the organization and analysis of sequence data. Bioinfor 28:1647-1649.

12. Armstrong DR, Berrisford JM, Conroy MJ, Gutmanas A, Anyango S, Choudhary P, Clark AR, Dana JM, Deshpande M, Dunlop R, Gane P, Gáborová R, Gupta D, Haslam P, Koča J, Mak L, Mir S, Mukhopadhyay A, Nadzirin N, Nair S, Paysan-Lafosse T, Pravda L, Sehnal D, Salih O, Smart O, Tolchard J, Varadi M, Svobodova-Vařeková R, Zaki H, Kleywegt GJ, Velankar S (2020) PDBe: improved findability of macromolecular structure data in the PDB. Nucleic Acids Res 48(D1):D335D343.

13. Croxen MA, Law RJ, Scholz R, Keeney KM, Wlodarska M, Finlay BB (2013) Recent Advances in understanding enteric pathogenic Escherichia coli. Clin Microbiol Rev 26(4):822-880.

14. Kadariya J, Smith TC, Thapaliya D (2014) Staphylococcus aureus and Staphylococcal food-borne disease: An ongoing challenge in public health. Emerging microbial concerns in Food Safety and New Control Measures Artilce ID 827965.

15. Bello 00, Babalola O0, Adegboye M, Fashola MO, Bello TK (2018) Partial purification, characterization and application of bacteriocin from bacteria isolated Parkia biglobosa NE Sci 3(2):72-94.

16. Milioni C, Martínez B, Degl'Innocenti S, Turchi B, Fratini F, Cerri D, Fischetti R (2015) A novel bacteriocin produced by Lactobacillus plantarum LpU4 as a valuable candidate for biopreservation in artisanal raw milk cheese. Dairy Sci Technol 95:479-494.

17. Barbosa MS, Todorov SD, Belguesmia Y, Choiset Y, Rabesona H, Ivanova IV, Chobert JM, Haertle T, Franco BDGM (2013) Purification and characterization of the bacteriocin produced by Lactobacillus sakei MBSa1 isolated from Brazilian salami. J Appl Microbiol 116:1195-1208.

18. Song DF, Zhu MY, Gu Q (2014) Purification and characterization of plantaricin ZJ5, a new bacteriocin produced by Lactobacillus plantarum PLoS ONE 9(8):e105549.

19. Todorov SD (2009) Bacteriocins from Lactobacillus plantarum-production, genetic organization and mode of action. Braz J Microbiol 40:209-221.

20. Nowroozi J, Mirzaii M, Norouzi M (2004) Study of Lactobacillus as probiotic bacteria. Iranian Journal of Public Health 33:1-7.

21. Sowani HM, Thorat P (2012) Antimicrobial activity studies of bactoriocin produced by Lactobacilli isolates from carrot kanji. OnLine J Biol Sci 12:6-10.

22. Martinez RC, Wachsman M, Torres NI, LeBlanc JG, Todorov SD, Franco BD (2013) Biochemical, antimicrobial and molecular characterization of a noncytotoxic bacteriocin produced by Lactobacillus plantarum Food Microbiol 34:376-381.

23. Mourad K, Halima ZK, Nour-Eddine K (2005) Detection and activity of plantaricin OL15 a bacteriocin produced by Lactobacillus plantarum OL15 isolated from Algerian fermented olives. Grasas y 
Aceites 56:192-197.

24. Zapata S, Muñoz J, Ruiz O, Montoya O, Gutierrez P (2009) Isolation of Lactobacillus plantarum LPBM10 and partial characterization of its bacteriocin. Vitae 16:75-82.

25. Todorov SD, Ho P, Vaz-Velho M, Dicks LM (2010) Characterization of bacteriocins produced by two strains of Lactobacillus plantarum isolated from Beloura and Chouriço, traditional pork products from Portugal. Meat Sci 84:334-343.

26. Lee NK, Paik HD (2001) Partial characterization of lactocin NK24, a newly identified bacteriocin of Lactococcus lactis NK24 isolated from Jeot-gal. Food Microbiol 18:17-24.

27. Ferchichi M, Frère J, Mabrouk K, Manai M (2001) Lactococcin MMFIl, a novel class Ila bacteriocin produced by Lactococcus lactis MMFII, isolated from a Tunisian dairy product. FEMS Microbiol Lett 205:49-55.

28. Hernández D, Cardell E, Zárate V (2005) Antimicrobial activity of lactic acid bacteria isolated from Tenerife cheese: initial characterization of plantaricin TF711, a bacteriocin-like substance produced by Lactobacillus plantarum J Appl Microbiol 99:77-84.

29. Todorov SD, Dicks LMT (2005) Lactobacillus plantarum isolated from molasses produces bacteriocins active against Gram-negative bacteria. Enz Microbial Technol 36:318-326.

30. Cintas L, Herranz C, Hernández P, Casaus M, Nes L (2001) Review: bacteriocins of lactic acid bacteria. Food Sci Technol Int 7:281-305.

31. Cotter PD, Ross RP, Hill C (2013) Bacteriocins-a viable alternative to antibiotics? Nature Rev Microbiol 11:95-105.

32. Todorov SD, van Reenen CA, Dicks LM (2004) Optimization of bacteriocin production by Lactobacillus plantarum ST13BR, a strain isolated from barley beer. J Gen Appl Microbiol 50:149157.

33. Todorov SD, Dicks LMT (2006) Screening for bacteriocin-producing lactic acid bacteria from boza, a traditional cereal beverage from Bulgaria: comparison of the bacteriocins. Process Biochem 46:1119.

34. Tomé E, Todorov SD, Gibbs PA, Teixeira PC (2009) Partial characterization of nine bacteriocins produced by lactic acid bacteria isolated from cold-smoked salmon with activity against Listeria monocytogenes. Food Biotechnol 23:50-73.

35. Messi P, Bondi M, Sabia C, Battini R, Manicardi G (2001) Detection and preliminary characterization of a bacteriocin (plantaricin 35d) produced by a Lactobacillus plantarum Int J Food Microbiol 64(12):193-198.

36. Arief II, Budiman C, Jenie BSL, Andreas E, Yuneni A (2015) Plantaricin IIA-1A5 from Lactobacillus plantarum IIA-1A5 displays bactericidal activity against Staphylococcus aureus. Beneficial Microbes 6(4):603-613.

37. Remiger A, Ehrmann MA, Vogel RF (1996) Identification of Bacteriocin-Encoding Genes in Lactobacilli by Polymerase Chain Reaction (PCR). System Appl Microbiol 19:28-34. 
38. Maldonado A, Jimenez-Diaz R, Ruiz-Barba JL (2004) Induction of plantaricin production in Lactobacillus plantarum NC8 after co-culture with specific gram positive bacteria is mediated by an autoinduction mechanism. J Bacteriol 86:1556-1564.

39. Rojo-Bezares B, Sáenz Y, Navarro L, Jiménez-Díaz R, Zarazaga M, Ruiz-Larrea F, Torres C (2008) Characterization of a new organization of the plantaricin locus in the inducible bacteriocin-producing Lactobacillus plantarum J23 of grape must origin. Arch Microbiol 189:491-499.

40. Ben Omar N, Abriouel H, Keleke S, Sanchez Valenzuela A, Martinez-Canamero M, Lucas Lopez R, Ortega E, Galvez A (2008) Bacteriocin producing Lactobacillus strains isolated from poto poto, a Congolese fermented maize product, and genetic fingerprinting of their plantaricin operons. Int $\mathrm{J}$ Food Microbiol 30:18-25.

41. Diep DB, Straume D, Kjos M, Torres C, Nes IF (2009) An overview of the mosaic bacteriocin pln loci from Lactobacillus plantarum. Peptides 30:1562-1574.

42. Devi SM, Halami PM (2019) Genetic variation of pln loci among probiotic Lactobacillusplantarum group strains with antioxidant and cholesterol lowering ability. Probiotics Antimicrob Proteins 11:1122.

43. Diep DB, Havarstein LS, Nes IF (1996) Characterization of the locus responsible for the bacteriocin production in Lactobacillus plantarum J Bacteriol 178:4472-4483.

44. Diep DB, Havarstein LS, Nissen-Meyer, Nes IF (1994) The gene encoding plantaricin A, a bacteriocin from Lactobacillus plantarum $\mathrm{C} 11$, is located on the same transcription unit as an agr-like regulatory system. Appl Environ Microbiol 60:160-166.

45. Noda M, Miyauchi R, Danshiitsoodol N, Matoba Y, Kumagai T, Sugiyama M (2018) Expression of genes involved in bacteriocin production and self-resistance in Lactobacillus brevis 174A is mediated by two regulatory proteins. Appl Environ Microbiol 84:e02707-02717.

46. Kristiansen PE, Fimland G, Mantzilas D, Nissen-Meyer (2005) Structure and mode of action of the membrane-permeabilizing antimicrobial peptide pheromone Plantaricin A. J Biol Chem 280(4):22945-22950.

\section{Tables}

Table 1 Antimicrobial activity of selected cultures during growth 


\begin{tabular}{|c|c|c|c|c|c|c|c|c|}
\hline \multirow[t]{2}{*}{ Culture } & \multirow[t]{2}{*}{$\begin{array}{l}\text { Incubation } \\
\text { period (hours) }\end{array}$} & \multirow{2}{*}{$\begin{array}{l}\text { Optical } \\
\text { density at } 600 \\
\mathrm{~nm}\end{array}$} & \multicolumn{2}{|c|}{$\begin{array}{l}\text { Inhibition zone } \\
\text { ( } \mathrm{mm} \text { in dia) }\end{array}$} & \multicolumn{2}{|c|}{ MIC $(\mu \mathrm{g})$} & \multirow{2}{*}{$\begin{array}{l}\text { Activity } \\
\text { protein) } \\
S . \\
\text { aureus } \\
\end{array}$} & \multirow{2}{*}{$\begin{array}{l}\text { (AU/mg } \\
\text { E. coli }\end{array}$} \\
\hline & & & $\begin{array}{l}S . \\
\text { aureus }\end{array}$ & E. coli & $\begin{array}{l}S . \\
\text { aureus }\end{array}$ & E. coli & & \\
\hline \multirow[t]{5}{*}{ DB-1 aa } & 24 & $3.45 \pm 0.01$ & $\begin{array}{l}16 \pm \\
0.00\end{array}$ & $\begin{array}{l}16 \pm \\
0.01\end{array}$ & $\begin{array}{l}2400 \\
\pm 0.02\end{array}$ & $\begin{array}{l}2400 \\
\pm \\
0.11\end{array}$ & $\begin{array}{l}96.00 \\
\pm 0.06\end{array}$ & $\begin{array}{l}96.00 \\
\pm 0.17\end{array}$ \\
\hline & 48 & $3.48 \pm 0.21$ & $\begin{array}{l}14 \pm \\
0.01\end{array}$ & $\begin{array}{l}14 \pm \\
0.01\end{array}$ & $\begin{array}{l}2500 \\
\pm 0.04\end{array}$ & $\begin{array}{l}2500 \\
\pm \\
0.05\end{array}$ & $\begin{array}{l}75.90 \\
\pm 0.11\end{array}$ & $\begin{array}{l}75.90 \\
\pm 0.28\end{array}$ \\
\hline & 72 & $3.79 \pm 0.22$ & $\begin{array}{l}12 \pm \\
0.00\end{array}$ & $\begin{array}{l}12 \pm \\
0.00\end{array}$ & $\begin{array}{l}2800 \\
\pm 0.12\end{array}$ & $\begin{array}{l}2800 \\
\pm \\
0.06\end{array}$ & $\begin{array}{l}26.04 \\
\pm 0.02\end{array}$ & $\begin{array}{l}26.04 \\
\pm 0.05\end{array}$ \\
\hline & 96 & $4.06 \pm 0.12$ & - & - & $\begin{array}{l}4900 \\
\pm 0.05\end{array}$ & $\begin{array}{l}4900 \\
\pm \\
0.11\end{array}$ & - & - \\
\hline & 120 & $3.76 \pm 0.11$ & - & - & $\begin{array}{l}5200 \\
\pm 0.06\end{array}$ & $\begin{array}{l}5600 \\
\pm \\
0.12 \\
\end{array}$ & - & - \\
\hline \multirow[t]{5}{*}{$\begin{array}{l}\text { Cu2- } \\
\text { PM7 }\end{array}$} & 24 & $3.38 \pm 0.21$ & $\begin{array}{l}16 \pm \\
0.01\end{array}$ & $\begin{array}{l}16 \pm \\
0.00\end{array}$ & $\begin{array}{l}2400 \\
\pm 0.05\end{array}$ & $\begin{array}{l}2400 \\
\pm \\
0.11\end{array}$ & $\begin{array}{l}266.02 \\
\pm 0.11\end{array}$ & $\begin{array}{l}133.01 \\
\pm 0.04\end{array}$ \\
\hline & 48 & $3.48 \pm 0.12$ & $\begin{array}{l}16 \pm \\
0.01\end{array}$ & $\begin{array}{l}16 \pm \\
0.01\end{array}$ & $\begin{array}{l}2400 \\
\pm 0.12\end{array}$ & $\begin{array}{l}2400 \\
\pm \\
0.23\end{array}$ & $\begin{array}{l}198.03 \\
\pm 0.14\end{array}$ & $\begin{array}{l}99.01 \\
\pm 0.02\end{array}$ \\
\hline & 72 & $3.61 \pm 0.03$ & $\begin{array}{l}16 \pm \\
0.01\end{array}$ & $\begin{array}{l}14 \pm \\
0.01\end{array}$ & $\begin{array}{l}2400 \\
\pm 0.22\end{array}$ & $\begin{array}{l}2400 \\
\pm \\
0.14\end{array}$ & $\begin{array}{l}80.58 \\
\pm 0.12\end{array}$ & $\begin{array}{l}40.29 \\
\pm 0.18\end{array}$ \\
\hline & 96 & $4.18 \pm 0.05$ & - & $\begin{array}{l}12 \pm \\
0.01\end{array}$ & $\begin{array}{l}4500 \\
\pm 0.11\end{array}$ & $\begin{array}{l}4500 \\
\pm \\
0.12\end{array}$ & - & $\begin{array}{l}37.30 \\
\pm 0.11\end{array}$ \\
\hline & 120 & $4.27 \pm 0.11$ & - & $\begin{array}{l}12 \pm \\
0.00\end{array}$ & $\begin{array}{l}5000 \\
\pm 0.22\end{array}$ & $\begin{array}{l}5200 \\
\pm \\
0.11\end{array}$ & - & $\begin{array}{l}15.04 \\
\pm 0.02\end{array}$ \\
\hline \multirow[t]{3}{*}{$\begin{array}{l}\text { Cu3- } \\
\text { PM8 }\end{array}$} & 24 & $3.48 \pm 0.12$ & $\begin{array}{l}15 \pm \\
0.00\end{array}$ & $\begin{array}{l}16 \pm \\
0.00\end{array}$ & $\begin{array}{l}2400 \\
\pm 0.15\end{array}$ & $\begin{array}{l}2400 \\
\pm \\
0.15\end{array}$ & $\begin{array}{l}178.8 \\
\pm 0.14\end{array}$ & $\begin{array}{l}89.39 \\
\pm 0.01\end{array}$ \\
\hline & 48 & $3.61 \pm 0.22$ & $\begin{array}{l}15 \pm \\
0.00\end{array}$ & $\begin{array}{l}16 \pm \\
0.00\end{array}$ & $\begin{array}{l}2400 \\
\pm 0.12\end{array}$ & $\begin{array}{l}2400 \\
\pm \\
0.21\end{array}$ & $\begin{array}{l}141.9 \\
\pm 0.12\end{array}$ & $\begin{array}{l}71.00 \\
\pm 0.01\end{array}$ \\
\hline & 72 & $3.70 \pm 0.14$ & $\begin{array}{l}15 \pm \\
0.01\end{array}$ & $\begin{array}{l}14 \pm \\
0.01\end{array}$ & $\begin{array}{l}2500 \\
\pm 0.14\end{array}$ & $\begin{array}{l}2500 \\
\pm \\
0.05\end{array}$ & $\begin{array}{l}67.32 \\
\pm 0.17\end{array}$ & $\begin{array}{l}67.32 \\
\pm 0.05\end{array}$ \\
\hline
\end{tabular}




\begin{tabular}{|c|c|c|c|c|c|c|}
\hline $4.10 \pm 0.06$ & - & $\begin{array}{l}12 \pm \\
0.01\end{array}$ & $\begin{array}{l}3800 \\
\pm 0.22\end{array}$ & $\begin{array}{l}3800 \\
\pm\end{array}$ & - & $\begin{array}{l}52.57 \\
\pm 0.06\end{array}$ \\
\hline $4.25 \pm 0.05$ & - & $\begin{array}{l}12 \pm \\
0.01\end{array}$ & $\begin{array}{l}3800 \\
\pm 0.05\end{array}$ & $\begin{array}{l}0.00 \\
3800 \\
\pm \\
0.01\end{array}$ & - & $\begin{array}{l}25.00 \\
\pm 0.11\end{array}$ \\
\hline
\end{tabular}

Values are average of two experiments performed individually (Mean \pm SD). '-' indicate no activity.

\section{Table 2 MIC and activity of AMC extracted with various methods}




\begin{tabular}{|c|c|c|c|c|c|c|c|c|c|}
\hline \multirow[t]{2}{*}{ Culture } & \multirow[t]{2}{*}{$\begin{array}{l}\text { Extraction } \\
\text { method }\end{array}$} & \multicolumn{4}{|c|}{$\begin{array}{l}\text { Inhibition zone } \\
\text { (mm in dia) }\end{array}$} & \multicolumn{2}{|c|}{ MIC ( $\mu g)$} & $\begin{array}{l}\text { Activity } \\
\text { protein) }\end{array}$ & (AU/ $\mathrm{mg}$ \\
\hline & & \multicolumn{2}{|c|}{$\begin{array}{l}S . \\
\text { aureus }\end{array}$} & \multicolumn{2}{|c|}{ E. coli } & $\begin{array}{l}S . \\
\text { aureus }\end{array}$ & E. coli & $\begin{array}{l}S . \\
\text { aureus }\end{array}$ & E. coli \\
\hline \multirow{8}{*}{$\begin{array}{l}\text { E. durans DB- } \\
1 \text { aa }\end{array}$} & 1 & - & & 10 & \pm & $6200 \pm$ & $2800 \pm$ & - & $60.39 \pm$ \\
\hline & & & & 0.01 & & 0.12 & 0.11 & & 0.11 \\
\hline & 2 & 12 & \pm & 15 & \pm & 2400 & $2300 \pm$ & $34.50 \pm$ & $69.00 \pm$ \\
\hline & & 0.01 & & 0.02 & & \pm 0.11 & 0.23 & 0.00 & 0.02 \\
\hline & 3 & - & & 12 & \pm & $6800 \pm$ & $2200 \pm$ & - & $15.79 \pm$ \\
\hline & & & & 0.01 & & 0.21 & 0.12 & & 0.00 \\
\hline & 4 & 15 & \pm & 14 & \pm & $2200 \pm$ & $2300 \pm$ & 155.27 & $155.27 \pm$ \\
\hline & & 0.01 & & 0.00 & & 0.11 & 0.11 & \pm 0.02 & 0.15 \\
\hline \multirow{8}{*}{$\begin{array}{l}L \\
\text { plantarum Cu2- } \\
\text { PM7 }\end{array}$} & 1 & - & & 10 & \pm & $6000 \pm$ & $3200 \pm$ & - & $80.47 \pm$ \\
\hline & & & & 0.01 & & 0.22 & 0.22 & & 0.11 \\
\hline & 2 & 14 & \pm & 15 & \pm & $2300 \pm$ & $2300 \pm$ & $92.31 \pm$ & $92.31 \pm$ \\
\hline & & 0.01 & & 0.01 & & 0.03 & 0.11 & 0.01 & 0.09 \\
\hline & 3 & 12 & \pm & 12 & \pm & $2800 \pm$ & $2800 \pm$ & $20.29 \pm$ & $20.29 \pm$ \\
\hline & & 0.02 & & 0.00 & & 0.05 & 0.05 & 0.03 & 0.00 \\
\hline & 4 & 18 & \pm & 14 & \pm & $1900 \pm$ & $2200 \pm$ & 319.08 & $212.72 \pm$ \\
\hline & & 0.01 & & 0.01 & & 0.06 & 0.21 & \pm 0.11 & 0.15 \\
\hline \multirow{8}{*}{$\begin{array}{l}L \\
\text { fermentum Cu3- } \\
\text { PM8 }\end{array}$} & 1 & - & & 10 & \pm & $6000 \pm$ & $3000 \pm$ & - & $31.76 \pm$ \\
\hline & & & & 0.01 & & 0.09 & 0.03 & & 0.11 \\
\hline & 2 & 14 & \pm & 14 & \pm & $3200 \pm$ & $3200 \pm$ & $83.01 \pm$ & $83.01 \pm$ \\
\hline & & 0.01 & & 0.00 & & 0.11 & 0.05 & 0.02 & 0.11 \\
\hline & 3 & 12 & \pm & 10 & \pm & $3800 \pm$ & $3800 \pm$ & $22.33 \pm$ & $22.33 \pm$ \\
\hline & & 0.02 & & 0.01 & & 0.12 & 0.11 & 0.00 & 0.02 \\
\hline & 4 & 18 & \pm & 18 & \pm & $2000 \pm$ & $2000 \pm$ & 179.80 & $179.80 \pm$ \\
\hline & & 0.02 & & 0.02 & & 0.11 & 0.09 & \pm 0.11 & 0.21 \\
\hline
\end{tabular}

Values are average of two experiments performed individually (Mean \pm SD). '-' indicate no activity. Extraction methods (1) Ethanol precipitation; (2) Chloroform extract (3) Butanol extraction (4) Ammonium Sulphate precipitation-dialysis 
Table 3 Summary of bacteriocin purification from selected cultures

\begin{tabular}{|c|c|c|c|c|c|c|c|c|c|}
\hline Isolate & $\begin{array}{l}\text { Purification } \\
\text { step }\end{array}$ & $\begin{array}{l}\text { Volume } \\
\text { (ml) }\end{array}$ & $\begin{array}{l}\text { Activity } \\
(\mathrm{AU} / \mathrm{ml})\end{array}$ & $\begin{array}{l}\text { Total } \\
\text { activity } \\
\text { (AU) }\end{array}$ & $\begin{array}{l}\text { Yield } \\
(\%)\end{array}$ & $\begin{array}{l}\text { Protein } \\
(\mathrm{mg} / \mathrm{ml})\end{array}$ & $\begin{array}{l}\text { Total } \\
\text { protein } \\
\text { (mg) }\end{array}$ & $\begin{array}{l}\text { Specific } \\
\text { activity } \\
(\mathrm{AU} / \mathrm{mg})\end{array}$ & $\begin{array}{l}\text { Purification } \\
\text { factor }\end{array}$ \\
\hline \multirow[t]{3}{*}{ DB-1aa } & CFS & 5000 & 160 & 800000 & 100.00 & 1.8 & 9000 & 88.90 & 1 \\
\hline & AS & 50 & 160 & 8000 & 1.00 & 1.03 & 51.50 & 155.34 & 1.75 \\
\hline & IE & 5 & 640 & 3200 & 0.4 & 2.62 & 13.10 & 244.27 & 2.75 \\
\hline \multirow{3}{*}{$\begin{array}{l}\text { Cu2- } \\
\text { PM7 }\end{array}$} & CFS & 5000 & 320 & 1600000 & 100.00 & 1.4 & 7000 & 228.57 & 1 \\
\hline & AS & 50 & 240 & 12000 & 0.75 & 0.75 & 37.50 & 320.00 & 1.40 \\
\hline & IE & 5 & 1600 & 8000 & 0.5 & 3.74 & 18.70 & 427.81 & 1.87 \\
\hline \multirow{3}{*}{$\begin{array}{l}\text { Cu3- } \\
\text { PM8 }\end{array}$} & CFS & 5000 & 320 & 1600000 & 100.00 & 2.3 & 11500 & 139.13 & 1 \\
\hline & AS & 50 & 160 & 8000 & 0.5 & 0.89 & 44.50 & 179.77 & 1.29 \\
\hline & IE & 5 & 1280 & 6400 & 0.4 & 4.8 & 24.00 & 266.67 & 1.92 \\
\hline
\end{tabular}

\begin{tabular}{|c|c|c|c|c|c|c|c|c|c|}
\hline Isolate & $\begin{array}{l}\text { Purification } \\
\text { step }\end{array}$ & $\begin{array}{l}\text { Volume } \\
\text { (ml) }\end{array}$ & $\begin{array}{l}\text { Activity } \\
\text { (AU/ml) }\end{array}$ & $\begin{array}{l}\text { Total } \\
\text { activity } \\
\text { (AU) }\end{array}$ & $\begin{array}{l}\text { Yield } \\
(\%)\end{array}$ & $\begin{array}{l}\text { Protein } \\
(\mathrm{mg} / \mathrm{ml})\end{array}$ & $\begin{array}{l}\text { Total } \\
\text { protein } \\
(\mathrm{mg})\end{array}$ & $\begin{array}{l}\text { Specific } \\
\text { activity } \\
(\mathrm{AU} / \mathrm{mg})\end{array}$ & $\begin{array}{l}\text { Purification } \\
\text { factor }\end{array}$ \\
\hline \multirow[t]{3}{*}{ DB-1aa } & CFS & 5000 & 160 & 800000 & 100.00 & 1.8 & 9000 & 88.9 & 1 \\
\hline & AS & 50 & 160 & 8000 & 1.00 & 1.03 & 51.50 & 155.34 & 1.75 \\
\hline & IE & 5 & 560 & 2800 & 0.35 & 2.62 & 13.10 & 213.74 & 2.4 \\
\hline \multirow{4}{*}{$\begin{array}{l}\text { Cu2- } \\
\text { PM7 }\end{array}$} & CFS & 5000 & 160 & 800000 & 100.00 & 1.4 & 7000 & 114.29 & 1 \\
\hline & & & & & & & & & \\
\hline & AS & 50 & 160 & 8000 & 1.00 & 0.75 & 37.50 & 213.33 & 1.87 \\
\hline & IE & 5 & 1216 & 6080 & 0.76 & 3.74 & 18.70 & 325.13 & 2.84 \\
\hline \multirow{3}{*}{$\begin{array}{l}\text { Cu3- } \\
\text { PM8 }\end{array}$} & CFS & 5000 & 160 & 800000 & 100.00 & 2.3 & 11500 & 69.56 & 1 \\
\hline & AS & 50 & 160 & 8000 & 1.00 & 0.89 & 44.50 & 179.77 & 2.58 \\
\hline & IE & 5 & 1088 & 5440 & 0.68 & 4.8 & 24.00 & 226.67 & 3.26 \\
\hline
\end{tabular}

Table 4 Stability of bacteriocin at different temperature 


\begin{tabular}{|c|c|c|c|c|c|c|c|c|c|c|c|c|}
\hline \multirow{3}{*}{$\begin{array}{c}\text { Temperature } \\
\left({ }^{\circ} \mathrm{C}\right)\end{array}$} & \multicolumn{12}{|c|}{ Inhibitory activity against Staphylococcus aureus } \\
\hline & \multicolumn{6}{|c|}{ Inhibition zone (mm dia) } & \multicolumn{6}{|c|}{ Activity (AU/mg protein) } \\
\hline & \multicolumn{2}{|c|}{ DB-1aa } & \multicolumn{2}{|c|}{$\begin{array}{l}\text { Cu2- } \\
\text { PM7 }\end{array}$} & \multicolumn{2}{|c|}{$\begin{array}{l}\text { Cu3- } \\
\text { PM8 }\end{array}$} & \multicolumn{2}{|c|}{ DB-1aa } & \multicolumn{2}{|c|}{ Cu2-PM7 } & \multicolumn{2}{|c|}{ Cu3-PM8 } \\
\hline \multirow[t]{2}{*}{30} & 15 & \pm & 15 & \pm & 15 & \pm & 240.12 & \pm & 426.20 & \pm & 263.12 & \pm \\
\hline & 0.01 & & 0.00 & & 0.01 & & 0.09 & & 0.11 & & 0.01 & \\
\hline \multirow[t]{2}{*}{40} & 15 & \pm & 15 & \pm & 15 & \pm & 244.12 & \pm & 429.30 & \pm & 265.73 & \pm \\
\hline & 0.00 & & 0.00 & & 0.01 & & 0.12 & & 0.12 & & 0.11 & \\
\hline \multirow[t]{2}{*}{50} & 15 & \pm & 15 & \pm & 15 & \pm & 242.03 & \pm & 425.20 & \pm & 261.42 & \pm \\
\hline & 0.02 & & 0.01 & & 0.01 & & 0.11 & & 0.11 & & 0.15 & \\
\hline \multirow[t]{2}{*}{60} & 15 & \pm & 15 & \pm & 15 & \pm & 252.02 & \pm & 419.70 & \pm & 260.12 & \pm \\
\hline & 0.01 & & 0.02 & & 0.00 & & 0.14 & & 0.15 & & 0.12 & \\
\hline \multirow[t]{2}{*}{70} & 15 & \pm & 15 & \pm & 15 & \pm & 241.15 & \pm & 415.60 & \pm & 261.12 & \pm \\
\hline & 0.01 & & 0.01 & & 0.02 & & 0.05 & & 0.21 & & 0.21 & \\
\hline \multirow[t]{2}{*}{80} & 15 & \pm & 15 & \pm & 15 & \pm & 252.05 & \pm & 411.07 & \pm & 260.09 & \pm \\
\hline & 0.01 & & 0.00 & & 0.02 & & 0.12 & & 0.15 & & 0.14 & \\
\hline \multirow[t]{4}{*}{90} & 15 & \pm & 15 & \pm & 15 & \pm & 226.70 & \pm & 409.10 & \pm & 255.02 & \pm \\
\hline & 0.01 & & 0.01 & & 0.00 & & 0.11 & & 0.06 & & 011 & \\
\hline & \multicolumn{12}{|c|}{ Inhibitory activity against $E$. coli } \\
\hline & \multicolumn{2}{|c|}{ DB-1aa } & \multicolumn{2}{|c|}{$\begin{array}{l}\text { Cu2- } \\
\text { PM7 }\end{array}$} & \multicolumn{2}{|c|}{$\begin{array}{l}\text { Cu3- } \\
\text { PM8 }\end{array}$} & \multicolumn{2}{|c|}{ DB-1aa } & \multicolumn{2}{|c|}{ Cu2-PM7 } & \multicolumn{2}{|c|}{ Cu3-PM8 } \\
\hline \multirow[t]{2}{*}{30} & 12 & \pm & 15 & \pm & 12 & \pm & 239.72 & \pm & 322.15 & \pm & 220.09 & \pm \\
\hline & 0.00 & & 0.00 & & 0.01 & & 0.12 & & 0.11 & & 0.11 & \\
\hline \multirow[t]{2}{*}{40} & 12 & \pm & 15 & \pm & 12 & \pm & 242.43 & \pm & 325.60 & \pm & 227.12 & \pm \\
\hline & 0.01 & & 0.00 & & 0.01 & & 0.15 & & 0.21 & & 0.21 & \\
\hline 50 & 12 & \pm & 15 & \pm & 15 & \pm & 241.03 & \pm & 322.30 & \pm & 225.03 & \pm \\
\hline & 0.02 & & 0.01 & & 0.01 & & 0.16 & & 0.11 & & 0.11 & \\
\hline 60 & 10 & \pm & 15 & \pm & 12 & \pm & 223.12 & \pm & 320.46 & \pm & 222.12 & \pm \\
\hline & 0.02 & & 0.02 & & 0.01 & & 0.11 & & 0.22 & & 0.11 & \\
\hline 70 & 10 & \pm & 15 & \pm & 10 & \pm & 212.06 & \pm & 319.60 & \pm & 209.73 & \pm \\
\hline & 0.11 & & 0.02 & & 0.00 & & 0.16 & & 0.06 & & 0.11 & \\
\hline 80 & 10 & \pm & 15 & \pm & 10 & \pm & 207.05 & \pm & 319.00 & \pm & 152.42 & \pm \\
\hline & 0.00 & & 0.01 & & 0.00 & & 0.21 & & 0.09 & & 0.06 & \\
\hline 90 & 10 & \pm & 15 & \pm & 10 & \pm & 200.18 & \pm & 312.90 & \pm & 169.12 & \pm \\
\hline & 0.00 & & 0.01 & & 0.01 & & 0.11 & & 0.11 & & 0.09 & \\
\hline
\end{tabular}

Values are average of two experiments performed individually (Mean \pm SD).

Table 5 Stability of bacteriocin at different $\mathrm{pH}$ 


\begin{tabular}{|c|c|c|c|c|c|c|}
\hline \multirow[t]{3}{*}{$\mathrm{pH}$} & \multicolumn{6}{|c|}{ Inhibitory activity against Staphylococcus aureus } \\
\hline & \multicolumn{3}{|c|}{ Inhibition zone (mm dia) } & \multicolumn{3}{|c|}{ Activity (AU/mg protein) } \\
\hline & DB-1aa & Cu2-PM7 & Cu3-PM8 & DB-1aa & Cu2-PM7 & Cu3-PM8 \\
\hline 3 & $15 \pm 0.00$ & $15 \pm 0.01$ & $18 \pm 0.01$ & $242.12 \pm 0.11$ & $422.12 \pm 0.11$ & $269.72 \pm 0.02$ \\
\hline 4 & $15 \pm 0.01$ & $15 \pm 0.00$ & $15 \pm 0.00$ & $245.72 \pm 0.05$ & $427.32 \pm 0.21$ & $266.32 \pm 0.11$ \\
\hline 5 & $15 \pm 0.01$ & $15 \pm 0.00$ & $15 \pm 0.01$ & $248.62 \pm 0.11$ & $426.32 \pm 0.14$ & $265.42 \pm 0.22$ \\
\hline 6 & $14 \pm 0.01$ & $14 \pm 0.01$ & $14 \pm 0.01$ & $240.12 \pm 0.14$ & $412.43 \pm 0.06$ & $252.42 \pm 0.09$ \\
\hline 7 & - & $10 \pm 0.01$ & - & $110.12 \pm 0.21$ & $400.23 \pm 0.06$ & $112.6 \pm 0.11$ \\
\hline 8 & - & - & - & $12.13 \pm 0.11$ & $32.0 \pm 0.05$ & - \\
\hline 9 & - & - & - & - & - & - \\
\hline \multirow[t]{3}{*}{10} & - & - & - & - & - & - \\
\hline & \multicolumn{6}{|c|}{ Inhibitory activity against $E$. coli } \\
\hline & DB-1aa & Cu2-PM7 & Cu3-PM8 & DB-1aa & Cu2-PM7 & Cu3-PM8 \\
\hline 3 & $14 \pm 0.00$ & $20 \pm 0.02$ & $12 \pm 0.00$ & $240.12 \pm 0.12$ & $326.70 \pm 0.12$ & $220.60 \pm 0.14$ \\
\hline 4 & $14 \pm 0.01$ & $14 \pm 0.01$ & $12 \pm 0.01$ & $244.72 \pm 0.06$ & $322.42 \pm 0.05$ & $222.60 \pm 0.15$ \\
\hline 5 & $14 \pm 0.01$ & $14 \pm 0.00$ & $12 \pm 0.01$ & $242.62 \pm 0.14$ & $319.06 \pm 0.11$ & $226.00 \pm 0.12$ \\
\hline 6 & $14 \pm 0.01$ & $14 \pm 0.00$ & $12 \pm 0.00$ & $240.32 \pm 0.06$ & $315.20 \pm 0.22$ & $215.90 \pm 0.15$ \\
\hline 7 & $14 \pm 0.00$ & - & - & $239.63 \pm 0.15$ & $109.20 \pm 0.21$ & $109.30 \pm 0.06$ \\
\hline 8 & - & - & - & $62.02 \pm 0.12$ & $32.60 \pm 0.11$ & $22.60 \pm 0.02$ \\
\hline 9 & - & - & - & - & - & - \\
\hline 10 & - & - & - & - & - & - \\
\hline
\end{tabular}

Values are average of two experiments performed individually (Mean \pm SD). '-' indicate no activity

Figures 

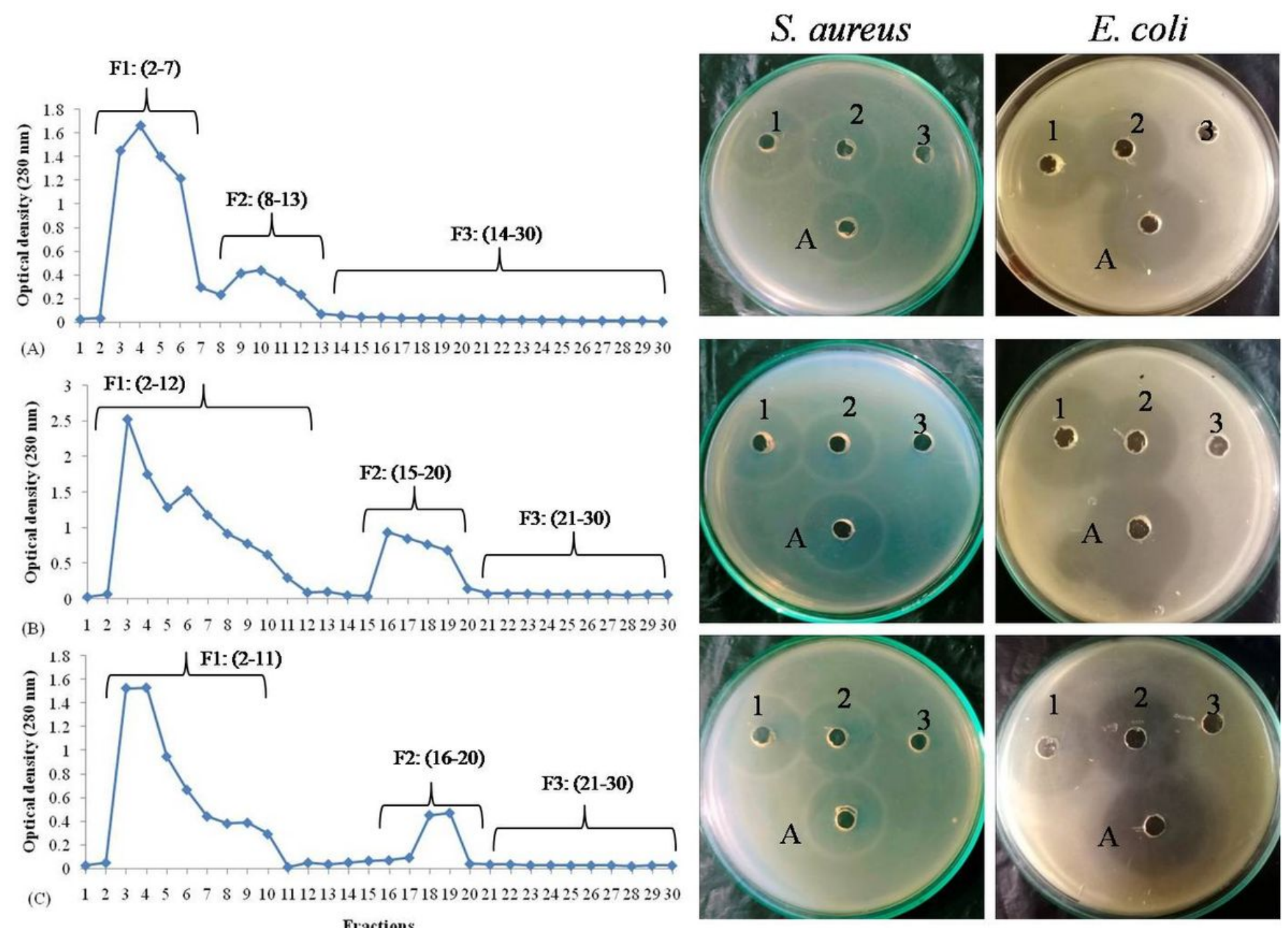

(A) $\quad 1223445667899101112131415161718192021222324252627282930$

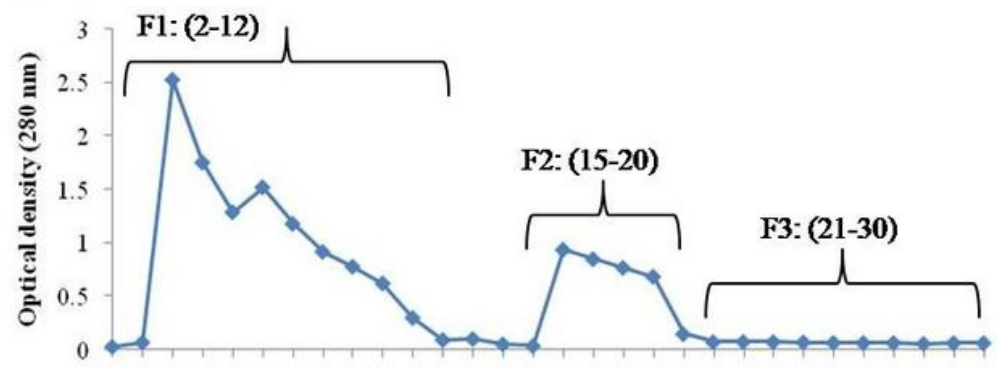

(B) $\quad 1223445667899101112131415161718192021222324252627282930$

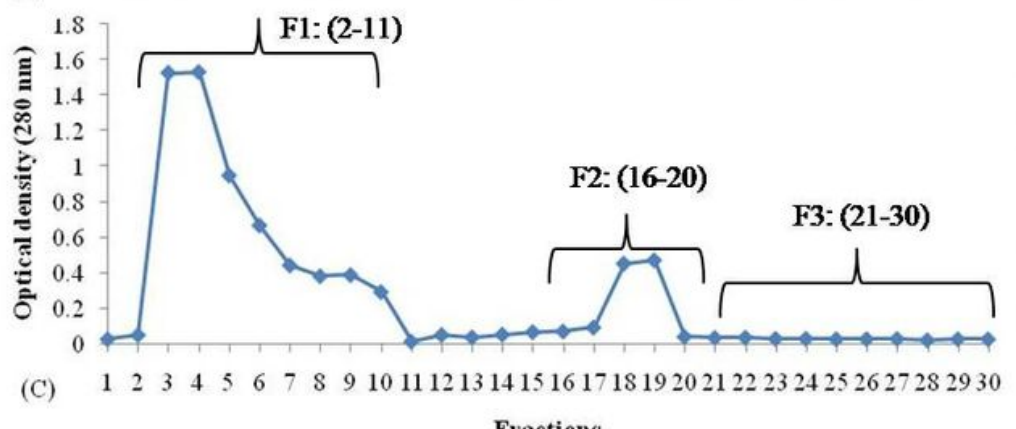

Figure 1

Elution profile of protein by ion-exchange chromatography. (A) E. durans DB-1aa; (B) L. plantarum Cu2PM7; (C) L. fermentum Cu3-PM8. Inhibitory activity of protein fractions (1, 2 and 3$)$ eluted by ionexchange chromatography against $\mathrm{S}$. aureus and E. coli. $A=$ Antibiotic chloramphenicol $(1 \mathrm{mg} / \mathrm{ml})$ was used as positive control 


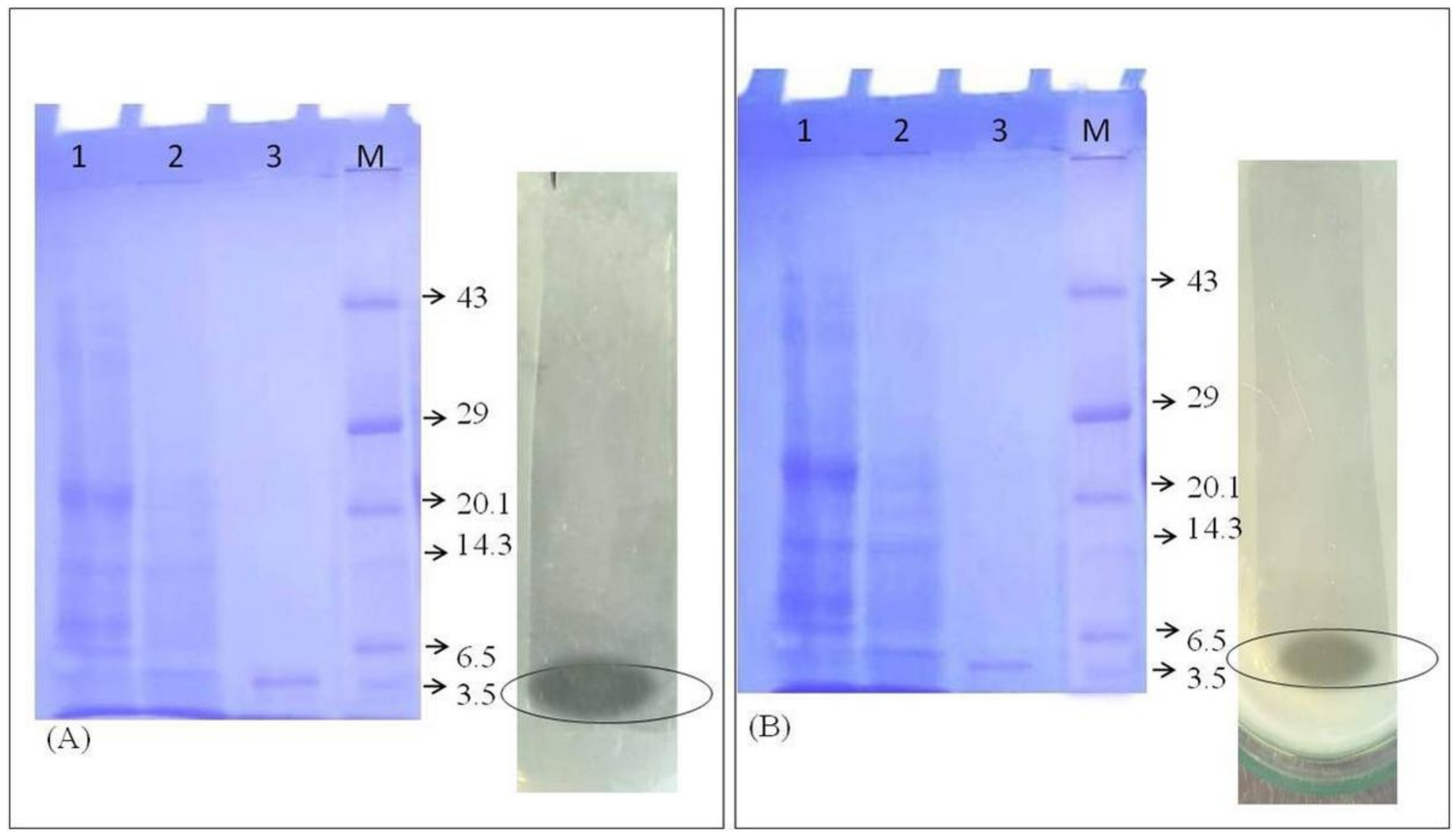

Figure 2

SDS-PAGE analysis of AMC (A) Cu2-PM7; (B) Cu3-PM8. (1) Crude; (2) Ammonium sulphate and dialyzed sample; (3) Column fraction; (M) Protein marker. Circle indicate inhibition zone in overlay plates 


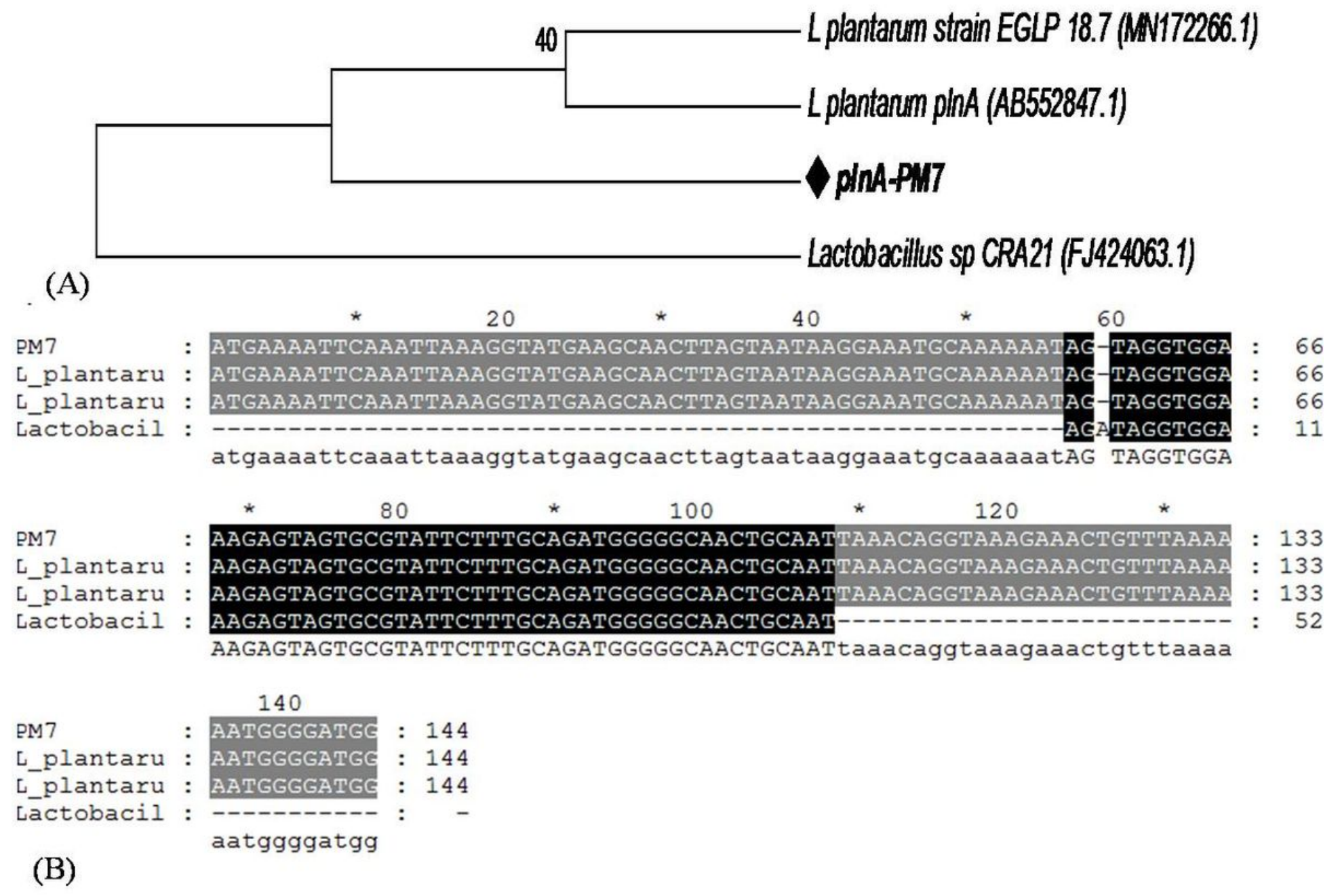

\section{Figure 3}

Plantaricin gene characterization (A) phylogenetic similarity between plnA-PM7 and related sequence from NCBI database (B) Sequences aligned (dark shade indicate maximum homology). 

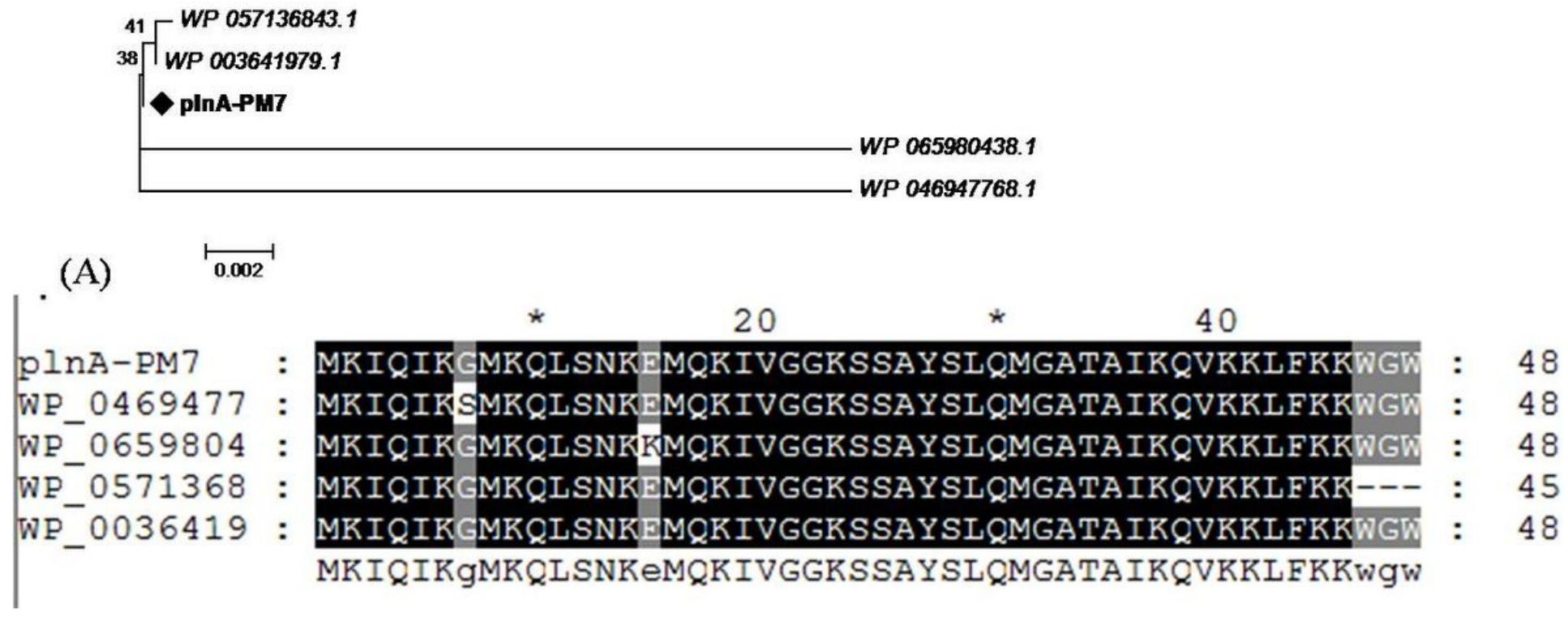

(B)

\section{Figure 4}

Plantaricin peptide analysis (A) Amino acid sequence similarity between plnA-PM7 and related sequence from NCBI data base (B) Amino acid sequence aligned (dark shade represents maximum homology)
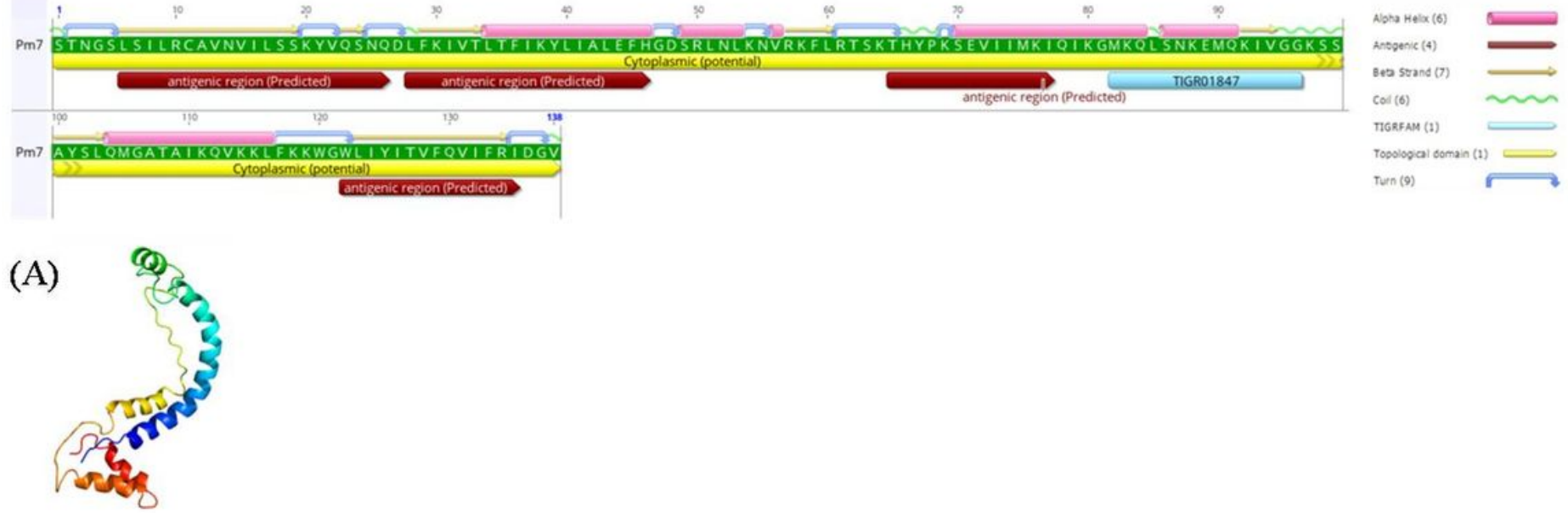

(B)

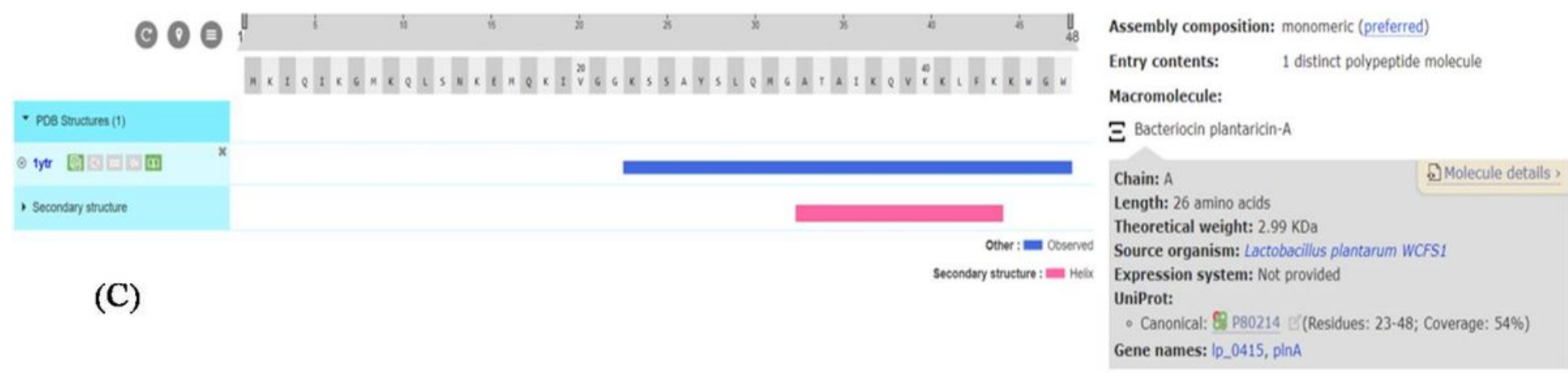

Figure 5 
Structure and functional analysis of Cu2-PM7 bacteriocin like peptide (A) Sequence analysis (B) 3D structure (C) Properties of active fraction

\section{Supplementary Files}

This is a list of supplementary files associated with this preprint. Click to download.

- supplementary1.docx 